DANIELLE THORNE

\title{
THE DOUBLE IRISH AND DUTCH SANDWICH TAX STRATEGIES: COULD A GENERAL ANTI- AVOIDANCE RULE COUNTERACT THE PROBLEMS CAUSED BY UTILISATION OF THESE STRUCTURES?
}

LLM RESEARCH PAPER

LAWS 516: TAXATION, DOMESTIC AND INTERNATIONAL

FACULTY OF LAW

TE WHARE WĀNANGA O TE ŪPOKO O TE IKA A MĀUI

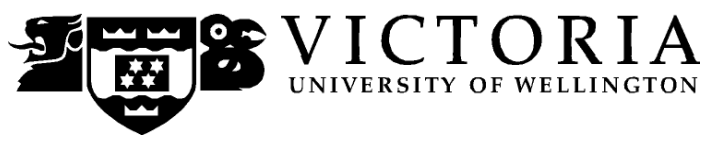

2013 


\begin{abstract}
This paper analyses the Double Irish and Dutch Sandwich tax structures used by large multinational enterprises. These structures enable companies to shift significant profits to offshore tax havens through the use of wholly owned subsidiaries in Ireland and the Netherlands. Application of the New Zealand General AntiAvoidance rule in s BG 1 of the Income Tax Act 2007 reveals that any attempt to counteract these structures would be highly fact dependent. The paper concludes that it would be possible to apply the rule, but that there would be practical difficulties in relation to enforceability of the Commissioner's ruling. A similar result was reached when applying the United States General Anti-Avoidance rule. The attempted application of the General Anti-Avoidance rules reveals a fundamental flaw in the income tax system. That is, the inability of the current system to regulate and control intangible resources and technology based transactions.
\end{abstract}

\title{
Word length
}

The text of this paper (excluding abstract, table of contents, footnotes and bibliography) comprises approximately 14,994 words.

\section{Subjects and Topics}

General Anti-Avoidance Rule

Income Tax Act 2007

Multinational Enterprises

Double Irish and Dutch Sandwich

Tax Avoidance 


\section{Contents}

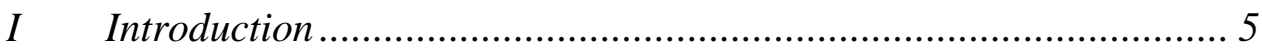

II Avoidance Strategies: The Double Irish and the Dutch Sandwich... 6

A Residency or Source Based Taxation .......................................... 7

B The Double Irish: Company Structure and Licensing Arrangements 8

C The Double Irish: Tax Benefits ............................................... 10

1 Circumvention of Subpart F ........................................... 11

D The Dutch Sandwich............................................................. 13

E A Specific Example: Apple ....................................................... 14

III Intellectual Property............................................................. 17

A Characteristics of Intellectual Property ......................................... 18

IV Are These Transactions Problematic? .......................................... 19

A Economic Effects........................................................... 19

B Consistency with the Rationale for Protecting Intellectual Property21

$V \quad$ Could the New Zealand GAAR Catch These Types of Strategies?... 21

A Income Tax Act 2007.............................................................. 22

B Judicial Interpretation and Application of the GAAR .................... 22

C Hypothetical Application of the GAAR to the Parent Company....... 26

1 Compliance with the Specific Provisions at Issue ................. 26

2 Step 1: Was there an Arrangement?.................................... 27

3 Step 2: Is the Purpose of the Arrangement within Parliamentary

Contemplation? ..................................................................... 28

4 Step 3: Application of the Commissioner's Powers of Reconstruction...................................................

D Hypothetical Application of the GAAR to the Subsidiaries............. 31

VI Why has the United States GAAR Not Been Applied? ...................... 33

A The United States Judicially Developed Anti-Avoidance Rule ...... 33

B The United States Statutory Rule ............................................. 35

1 Objective element: meaningful change to taxpayer's position..................................................... 37

2 Subjective element: substantial non-tax purpose? ................ 37

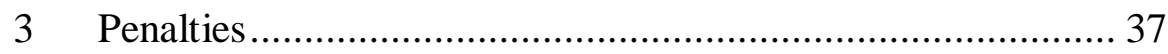

C Application of the United States GAAR to the Parent Company ..... 38

1 Application of the doctrine to the single licensing transaction................................................ 38

2 Application of the doctrine to the scheme as a whole ............ 40

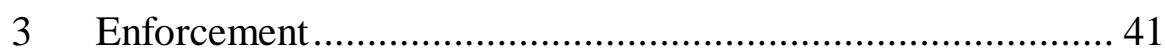

VI Does Use of the Commissioner's Powers of Reconstruction Implicate the Separate Entity Doctrine? ............................................................ 43 
A New Zealand ........................................................................... 43

B The United States........................................................................ 45

C An Alternative Resolution for the Corporate Veil Argument ......... 47

VII Conclusion.................................................................................. 48

VIII Bibliography ................................................................... 50 


\section{Introduction}

In the late $20^{\text {th }}$ century and into the $21^{\text {st }}$ century several fundamental changes have occurred in the way we do business. The rise of the multinational enterprise has led to trading on a truly global level.

5 Companies are now able to set up subsidiaries and branches wherever they wish. Technological developments have a twofold effect here. First, the rise of the internet has enabled agreements and transactions to be made instantaneously. Secondly, any new technologies require intellectual property protection. Thus, there is an abundance of

10 intangible intellectual property assets that previously did not make a substantial contribution to the economy. The combination of technological developments and the abundance of intellectual property means the business world no longer resembles the environment many of our laws were designed to deal with. Amongst these is income tax

15 law. The fundamentals of the western income tax system were formulated at a time where it was easier to keep track of trade, and thus income could be easily assessed. Trade generally encompassed some form of physical transfer of goods, and the tangible nature of these transactions meant that regulation of income tax was relatively

20 straightforward.

By contrast, in the $21^{\text {st }}$ century, a significant amount of goods and services rely on the use and/or provision of intangible intellectual property resources. The abundance of technology in society has led to massive growth in the intellectual property industry, particularly patents. Technology developers rely on patents, and to a certain extent trade marks and copyright, to protect both their brands and products.

The result of a rapid change in the type of assets being dealt with, and the use of these assets, has resulted in a tax system that is poorly equipped to deal with a significant proportion of transactions. ${ }^{1}$ Corporations are therefore able to engage in tax strategies that comply with the strict letter of the law, but do not uphold the spirit or purpose of the law. ${ }^{2}$ This paper will examine the company structures and transactions used by technology-rich companies in order to exploit

35 these out-dated laws and to avoid corporate income tax. The paper will then focus on exploring whether there are any feasible solutions other than a complete reform of the income tax system.

\footnotetext{
${ }^{1}$ James Fryer “The Price Isn't Right: Corporate Profit Shifting has Become Big Business" (16 February 2013)<www.theeconomist.com>.

2 John VanDenburgh "Closing International Loopholes: Changing the Corporate Tax Base to Effectively Combat Tax Avoidance" (2012) 47 Val U L Rev 313 at 327.
} 
Part II of the paper will outline the commonly used Double Irish and Dutch Sandwich strategies for tax avoidance in respect of intellectual property. This will involve consideration of both the company structures employed and the effect of the relevant transactions occurring within those structures. Included in this part will be a description of the laws that are being exploited to enable these structures to function. Following this, examination of Apple Incorporated will provide a concrete example of the benefits obtained by the companies when using these structures.

10 Part III of the paper then goes on to explain the specific features of intellectual property that allow the Double Irish and Dutch Sandwich to function effectively.

Part IV of the paper will build on the explanation of the features of intellectual property to show the problematic nature of these

15 structures, from both an economic point of view and an intellectual property point of view. Tax avoidance is a major issue facing governments around the world, as income tax is one of the government's main sources of funds. In the context of intellectual property, there is also a concern that there is no connection between

20 the place where the economic activity resulting from the intellectual property occurs, and the place where the intellectual property is developed and created. Therefore allowing these transactions and structures to be used is inconsistent with the traditional rationale for protection of intellectual property.

25 The paper will then analyse several possible measures that could be taken to counteract the Double Irish and Dutch Sandwich structures. The applicability of a general anti-avoidance rule (GAAR) in the form of the New Zealand GAAR will be considered, in addition to consideration of the United States GAAR. The final part of the paper

30 will consider whether the separate entity doctrine is implicated in any attempt to resolve the problem.

\section{Avoidance Strategies: The Double Irish and the Dutch Sandwich}

Intellectual property assets have the valuable feature of being

35 intangible, enabling them to be licensed and transferred between companies and jurisdictions with relative ease. Where companies have large numbers of intangible assets, namely intellectual property, strategies such as the Double Irish and Dutch Sandwich are often used 
to avoid paying income tax. This behaviour is increasingly prevalent amongst technology based firms such as Apple Inc., Google Inc., and Microsoft Corporation. These strategies were pioneered by Apple, and are favoured because they enable facile offshore profit shifting. ${ }^{3}$ Ireland is the favoured destination for these transactions due to a combination of several factors, including a low corporate tax rate, favourable tax treaties that limit the tax on transactions between subsidiaries, and a well-educated and English speaking workforce. ${ }^{4}$

\section{A Residency or Source Based Taxation}

10 There are two fundamental concepts in income tax that are often exploited by tax avoiders. ${ }^{5}$ The first is the basis for income tax. Income tax systems are generally based either on source of income (territorial system), or on the residency of the taxpayer (worldwide system). It is generally accepted that both the source country and the residence country have a valid claim to tax certain income. ${ }^{6}$ In a system based on source of income, the taxpayer will be liable to pay tax on income earned within the jurisdiction of the taxing state. By contrast, in a system based on residency, once a taxpayer is deemed to be a resident in the taxing state they will be liable to pay income tax on their worldwide income. ${ }^{7}$ Many states will use a combination of the territorial and worldwide systems. This is true of both the United States and New Zealand. ${ }^{8}$

\footnotetext{
${ }^{3}$ Steven Bank "The Globalisation of Corporate Tax Reform" (2013) 40 Pepperdine Law Review 1307 at 1310.

${ }^{4}$ John Sokatch "Transfer-Pricing with Sofware Allows for Effective Circumvention of Subpart F Income: Google's 'Sandwich' Costs Taxpayers Millions" (2011) 45 Int'l Law 725 at 732 .

${ }^{5}$ This section is not intended to be a comprehensive discussion of the issues arising from taxing on the basis of source or residency. It is merely intended to provide a background to the following discussion and explain why the relevant rules are able to be exploited.

${ }^{6}$ Michael J Graetz Foundations of International Income Taxation (Foundation Press, New York, 2003) at 5. It is important to recognise that this creates the potential for double taxation. A discussion of issues relating to double taxation is superfluous to this paper.

${ }^{7}$ VanDenburgh, above $\mathrm{n} 2$, at 321

${ }^{8}$ In the United States a corporation will be taxed on worldwide income if it is resident in the United States. A foreign company will also be taxed by the United States if its income is earned within the United States. Income earned by offshore subsidiaries will not be taxed unless it is repatriated to the United States. New Zealand taxes income on both a residency and source basis. When a corporation is resident in New Zealand, it will be taxed on worldwide income, that is, income derived from sources within and outside of New Zealand. Income earned by a Controlled Foreign Corporation will be attributed to the New Zealand resident shareholder if the interest is greater than 10 per cent, and the Controlled Foreign Corporation is not an active business. The offshore subsidiaries discussed in the
} 
The second fundamental concept is the manner of determining residency. For example, when determining whether a corporation is a resident for tax purposes, some states will use a test based on place of incorporation, while some states will determine residency based on where the management and control of the company is located. For example, Ireland determine company residency using a test of management and control, while the United States determine company residency based on place of incorporation.

Both of these concepts are central to the explanation of how the

10 Double Irish and Dutch Sandwich structures exploit different tax systems. The differences in residency rules are fundamental to the effective functioning of the Double Irish and Dutch Sandwich structures, as the parent company exploits the difference in rules to create subsidiaries with no legal residency.

15 B The Double Irish: Company Structure and Licensing Arrangements

The Double Irish strategy involves taking advantage of a feature of Irish tax law that allows a company based overseas to be registered as an Irish company. ${ }^{9}$ The predominant feature of this arrangement is

20 that the parent corporation wishing to avoid a corporate tax bill will set up a subsidiary in Ireland (B). Subsidiary B will then set up a wholly owned subsidiary (S), also in Ireland. The name of the structure comes from use of two Irish incorporated subsidiaries.

The default position is now that a company incorporated in Ireland

25 will be treated as resident in Ireland for tax purposes. ${ }^{10}$ However, the Finance Act 1999 introduced several exceptions to this rule, one of which enables subsidiary B to be deemed an overseas resident, despite being incorporated in Ireland.

For the purpose of the Double Irish, the applicable exception is that 30 an Irish company will not be treated as resident for tax purposes if it is a relevant company, and it carries on trade in Ireland. ${ }^{11}$ For a company to be classified as a relevant company, it must be controlled by a European Union resident, or by a company residing in a country that has a double-taxation treaty with Ireland. ${ }^{12}$ Therefore, because

following part of the paper are wholly owned by the parent company, and therefore fall within the definition of a Controlled Foreign Company in New Zealand.

${ }^{9}$ Peter Flanagan "How this Double Irish accountancy trick works" (27 May 2013)

<www.independent.ie>.

${ }^{10}$ Finance Act 1999, s 23A(1)(a) (Ireland).

${ }^{11}$ Finance Act 1999, s 23A(3) (Ireland).

${ }^{12}$ Finance Act 1999, s 23A(3) (Ireland). 
Ireland has a double-taxation agreement with the United States, ${ }^{13}$ subsidiary B can avoid being classed as an Irish resident for tax purposes. Subsidiary B will be incorporated in Ireland, but for the purposes of Irish tax law, it will be deemed to be a resident of an overseas tax haven, for example Bermuda. ${ }^{14}$

Subsidiary B also avoids having United States residency because the United States rules are based on the source of income rather than the country of incorporation. That is, corporate income tax is imposed on all domestic corporations, and on some foreign corporations that

10 have income or activities in the jurisdiction. ${ }^{15}$ The definition of domestic corporation includes corporations that are created in the United States. ${ }^{16}$ It is the difference between the United States residency rules and the Irish residency rules that enables the Double Irish and Dutch Sandwich to function. By incorporating subsidiaries

15 overseas, the parent company ensures that the income of these subsidiaries is outside the reach of the United States Internal Revenue Service.

Subsidiary B will have its effective centre of management in a tax haven, and therefore will be treated as a resident of the tax haven for

20 the purpose of Irish taxation. The centre of management and control is determined by reference to the location where the strategic and policy aspects of the company are determined. ${ }^{17}$ As a consequence, if subsidiary B has its effective centre of management in Bermuda, it will not be subject to any corporate income tax, as there is no

25 corporate income tax in Bermuda, and it is not deemed to be a resident of any other state.

The second subsidiary (S) will be wholly owned by subsidiary B, and will be incorporated in Ireland. ${ }^{18}$ For Irish tax purposes, subsidiary $\mathrm{S}$ will be classed as an Irish resident.

\footnotetext{
${ }^{13}$ Convention Between the Government of Ireland and Government of the United States of America for the Avoidance of Double Taxation and the Prevention of Fiscal Evasion With Respect to Taxes on Income and Capital Gains, Ireland-United States (signed 28 July 1997).

${ }^{14}$ Bank, above $\mathrm{n} 3$ at 1311.

${ }^{15}$ Internal Revenue Code 26 USC § 7701(a)(4).

${ }^{16}$ Internal Revenue Code 26 USC § 7701(a)(4).

17 John Hickson "Corporate Migrations to Ireland" (2010) 36 International Tax Journal 25 at 27.

${ }^{18}$ Joseph B Darby "Double Irish More than Doubles the Tax Saving: Hybrid Structure Reduces US, Irish and Worldwide Taxation" (2007) 11(9) Practical US/International Tax Strategies 2 at 13.
} 


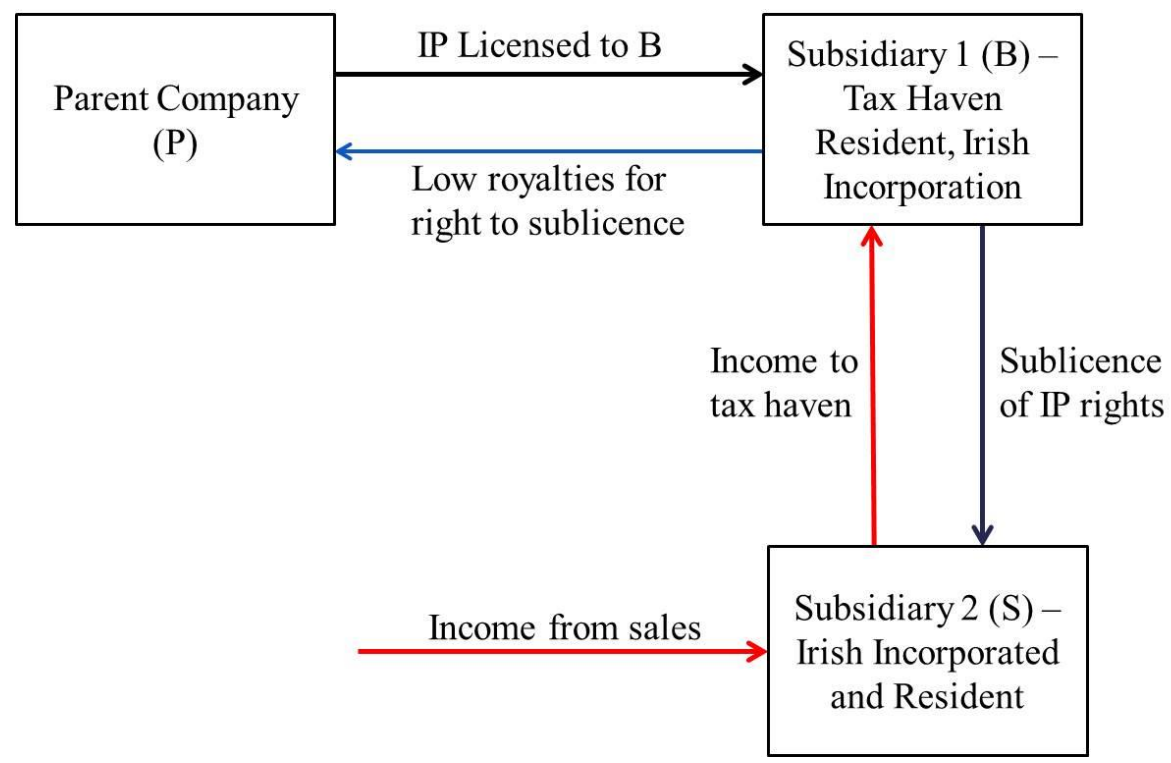

Figure 1: The Double Irish Company Structure and Licensing Arrangements

5 Once the above company structure is set up, licensing arrangements involving intellectual property will enable profit shifting. The parent company will license its intellectual property rights to subsidiary B. In return, subsidiary B will pay low royalties to the parent company. Subsidiary B will then grant a sublicense of the

10 intellectual property rights to subsidiary $S$. This sublicense enables subsidiary $S$ to exploit the rights, meaning that all income from sales and use of the intellectual property outside of the parent company's home state will go to subsidiary S. ${ }^{19}$ Subsidiary S will then pay substantial royalties and licence fees to Subsidiary B for their use of 15 the intellectual property. This essentially funnels the majority of income to Subsidiary B, where it can sit tax free in an offshore tax haven. ${ }^{20}$

\section{The Double Irish: Tax Benefits}

The overall arrangement provides significant tax benefits to the parent

20 company. The only income that the parent company receives is income from local sales and use of the intellectual property rights. This means that the pre-tax income of the parent company is significantly less than it would be if it was receiving the income from the worldwide sales and use of the intellectual property. The

25 transaction thereby lowers the incidence of income tax for the parent

${ }^{19}$ Bank, above n 3, at 1311.

20 Stephen C Loomis "The Double Irish Sandwich: Reforming Overseas Tax Havens” (2012) 43 St Mary’s Law Journal 825 at 839. 
company. Under a cost sharing agreement, some expenses of the subsidiaries will also be attributed to the parent company so that the company is able to make deductions that further reduce the tax bill of the parent company. ${ }^{21}$

The main tax benefit of the transaction arises because subsidiary B is situated in a country that has little or no corporate income tax, for example Bermuda. As a consequence, if the profits reside there, they will be tax-free until such time as the parent company wishes to use the money. The money can often be repatriated to the United States

10 without the usual income tax consequences by exploiting several loopholes in the Federal Tax Code. ${ }^{22}$ Repatriation of funds by an offshore subsidiary incurs federal income tax under $\S 881$ of the Federal Tax Code. ${ }^{23}$

\section{$1 \quad$ Circumvention of Subpart F}

15 Under the Federal Tax Code controlled foreign corporations not engaged in United States trade or business are not taxed by the United States on their profits. Therefore, prior to the introduction of Subpart $\mathrm{F}$, there was significant opportunity for a United States corporation to shift its operations to an offshore subsidiary. Subpart F was

20 introduced to mitigate this by introducing rules relating to personal holding companies, foreign personal holding companies, and controlled foreign corporations.

In relation to the Double Irish and Dutch Sandwich, the first relevant rule is the Foreign Base Company Sales Income rule. Income

25 earned by a foreign subsidiary will be taxable when the subsidiary does not materially participate in the generation of the income, and the subsidiary either buys or sells personal property from or to a related party. ${ }^{24}$ Under this rule, the income of subsidiary B would ordinarily be taxable as neither subsidiary B or subsidiary $\mathrm{S}$ participates in the generation of income, and the subsidiary is buying personal property from a related party in the form of intellectual property rights.

The second relevant rule in regard to the Double Irish and Dutch Sandwich structures is the Foreign Personal Holding Company Income rule. The rule is designed to tax interest, dividends, royalties

\footnotetext{
${ }^{21}$ Carl Levin and John McCain "Offshore Profit Shifting and the US Tax Code Part 2 (Apple Inc)" (memorandum to the Members of the Permanent Subcommittee on Investigations, 21 May 2013) at 9.

${ }^{22}$ Loomis, above n 20 at 839.

${ }^{23}$ Internal Revenue Code 26 USC $\$ 881$.

${ }^{24}$ Internal Revenue Code 26 USC $§ \S 954(d)$.
} 
and other passive income that is earned by a foreign subsidiary. ${ }^{25}$ Thus, it would appear that the substantial income of subsidiary B should also be caught by the Foreign Personal Holding Company Income rule as its income is in the form of royalties in return for a sublicense of intellectual property rights.

The effectiveness of these Subpart F rules has been weakened by statutory changes. In particular, the check-the-box-rules are often used to enable exploitation of Subpart F. ${ }^{26}$ The check the box rules allow a domestic or foreign business entity to elect whether it will be 10 treated as a corporation or a pass-through entity ${ }^{27}$ for the purposes of the Federal Tax Code. This rule creates what are known as hybrid entities. $^{28}$ The company can elect to be taxed as an entity in one tax jurisdiction and taxed as a disregarded (or pass-through) entity in the other jurisdiction. The parent company based in the United States can

15 therefore elect that the other subsidiaries are to be treated as disregarded. When check-the-box elections are made on multiple subsidiaries of a United States based parent company, the subsidiaries are treated as a single entity for United States tax purposes. Therefore any transactions between the subsidiaries will not be taxable under

20 United States law. ${ }^{29}$ In the Double Irish and Dutch Sandwich this means that United States law will not tax payments from subsidiary $\mathrm{S}$ to subsidiary B. ${ }^{30}$

The usual position is that the transactions between subsidiaries would fall within the scope of the Foreign Base Company Sales

25 Income rule. However, by making a check-the-box election the parent company avoids paying the Foreign Base Company Sales Income tax. $^{31}$ The check-the box election also enables avoidance of the Foreign Personal Holding Company Income tax, as the disregarded status of the entities means any dividends or royalties paid to 30 Subsidiary B are also not taxable. ${ }^{32}$

The above discussion illustrates that use of a European based subsidiary to funnel income into a tax haven is necessary to enable circumvention of the Foreign Base Company Sales Income and

\footnotetext{
${ }^{25}$ Internal Revenue Code 26 USC §§ 954(c).

${ }^{26}$ Levin and McCain, above $\mathrm{n} 21$, at 5.

${ }^{27}$ A pass through entity arises where the income of the entity is treated as the income of the shareholder owners

${ }^{28}$ VanDenburgh, above $\mathrm{n} 2$, at 330 .

${ }^{29}$ J Richard Harvey "Testimony Before the US Senate Permanent Subcommittee on Investigations" (21 May, 2013) at 20.

${ }^{30}$ Darby, above n 18, at 13.

${ }^{31}$ Harvey, above $\mathrm{n} 29$, at 20.

${ }^{32}$ Harvey, above n 29, at 20.
} 
Foreign Personal Holding Company Income rules. If the arrangement simply involved a licence transaction by the parent company to the subsidiary in a tax haven, the income would be taxed at the usual United States rate under the Controlled Foreign Company rules.

The overall tax bill for subsidiary $\mathrm{S}$ is also lowered by this arrangement because royalties or fees paid by subsidiary $S$ to subsidiary B are deductible expenses. ${ }^{33}$ As a consequence, despite having a very large income, the scale of the deductible expenses means subsidiary $\mathrm{S}$ will have a low taxable income. When compared

10 to the amount of profits being made, the effective tax rate on those profits is much lower than the corporate income tax rate in Ireland. ${ }^{34}$

D The Dutch Sandwich

The Dutch Sandwich structure is largely similar to the Double Irish. The key difference is that the Dutch Sandwich employs a third

15 subsidiary, N. This subsidiary will be situated in the Netherlands, and will typically be a shell company. ${ }^{35}$ That is, it will have no employees, no physical presence in the country and will not produce any goods or services. ${ }^{36}$ In the Double Irish structure described above, the income from sales and exploitation of the intellectual

20 property is transferred to subsidiary B in the form of extensive royalty payments and dividends. By contrast, in the Dutch Sandwich, the income is shifted to subsidiary $\mathrm{N}$ before being transferred to subsidiary B. ${ }^{37}$

Under EC Directive 2003/49 interest and royalty payments made

25 by a corporation in one European Union member state to a subsidiary in another European Union member state will not be taxed provided the beneficial owner of the payment is a company or a permanent establishment in another member state. ${ }^{38}$ These transactions enable subsidiary $S$ to avoid any Irish withholding tax payments that they would otherwise be liable to pay. ${ }^{39}$

\footnotetext{
${ }^{33}$ Loomis, above $\mathrm{n} 20$, at 839.

${ }^{34}$ The corporate income tax rate in Ireland is currently at $12.5 \%$.

${ }^{35}$ Bank, above n 3, at 1311.

${ }^{36}$ Levin and McCain, above n 21, at 10.

${ }^{37}$ Bank, above n 3, at 1311.

${ }^{38}$ Directive 2003/49 on the Taxation of Cross-Border Interest and Royalty Payments in the European Union, OJ L 157, P. 0049 - 0054, Article 1.

${ }^{39}$ Fryer, above n 1 . See also Sokatch, above n 4, at 741.
} 


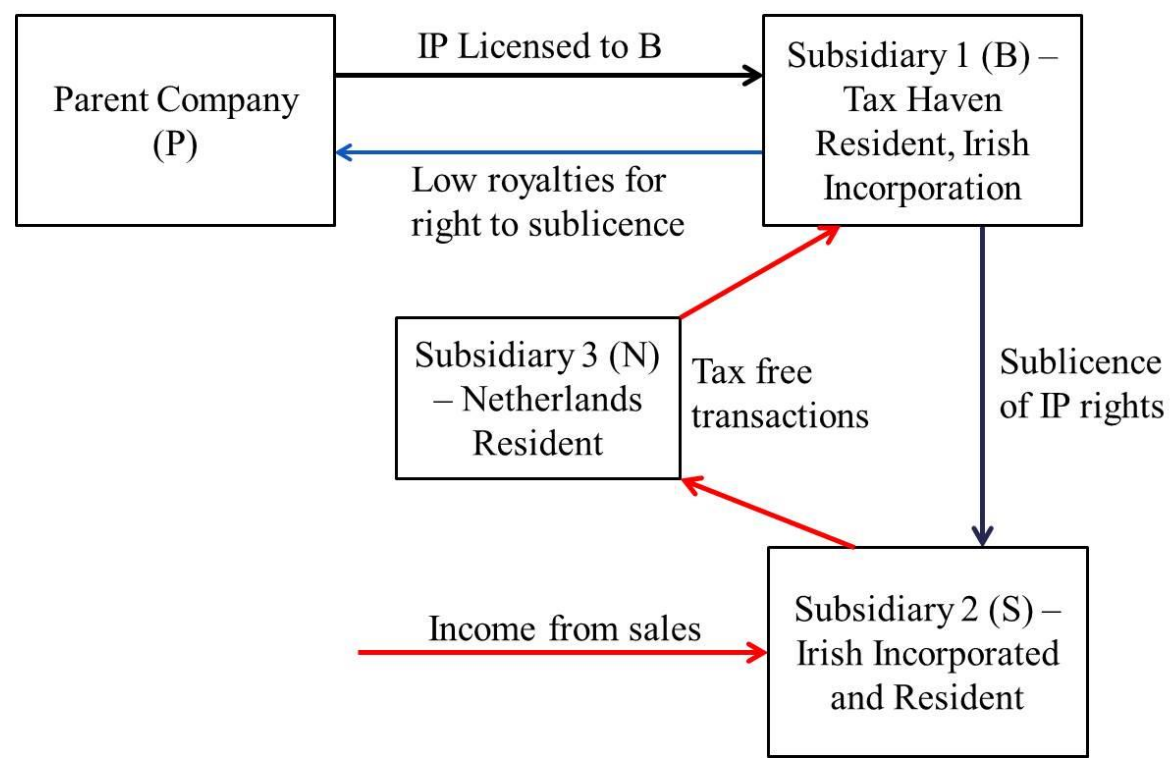

Figure 2: The Dutch Sandwich Company Structure and Licensing Arrangements

\section{E A Specific Example: Apple}

5 The example of Apple will be used to give a specific example of use of a structure similar to the Double Irish. The scale of the avoidance undertaken by Apple is such that in 2013 the Senate Permanent Subcommittee of Investigations began investigating Apple as part of its review of offshore profit shifting and the tax code.

10 In 2013, Apple was one of the most profitable companies in the world, with over USD 145 billion in cash, cash equivalents and marketable securities. ${ }^{40}$ It was founded in the United States in 1976, and its primary marketing and research and development operations remain in the United States. Apple also has significant offshore

15 holdings, with its Irish operations having been in operation since 1980. ${ }^{41}$ Despite being a United States based company, around USD 102 billion of its total assets reside overseas, and are thus not subject to United States corporate income tax. ${ }^{42}$

The company structure employed by Apple is complex, and results

20 in a clear separation of United States sales and business from offshore sales and business. Apple Inc. has a wholly owned subsidiary, Apple Operations International, which is incorporated in Ireland. Apple Operations International is a holding company that is the primary owner of the majority of the other related entities. Apple Singapore,

\footnotetext{
${ }^{40}$ Levin and McCain, above $\mathrm{n} 21$, at 5 .

41 "Testimony of Apple Before The Permanent Subcommittee On Investigations" (US Senate, 21 May 2013) at 8.

${ }^{42}$ Levin and McCain, above n21, at 17.
} 
Apple Operations Europe and Apple Distributions International are all wholly owned subsidiaries of Apple Operations International. ${ }^{43}$ Apple Distributions International and Apple Operations Europe are also incorporated in Ireland. Apple Sales International is a wholly owned Irish subsidiary of Apple Operations Europe. Unlike Apple Operations International, Apple Sales International is taxed in Ireland as it is treated as an Irish resident.

Apple Operations International is a shell company, and despite being incorporated in Ireland it has no physical presence there and has never had any employees. It has three directors, all of whom are employees of other Apple companies. The assets of Apple Operations International are managed in the United States by another subsidiary, Braeburn Capital. ${ }^{44}$ The consequence of the management and control of the company being in the United States is that the company has no

15 declared tax residency. ${ }^{45}$ Apple Operations International are the primary recipient of the funds obtained from offshore sales and investments, and they consolidate and manage these funds in a way that enables the business to grow and develop without needing to repatriate the income to the United States. This is a necessary step in

20 the tax avoidance scheme because repatriation of the income to a United States resident corporation would incur a 35 per cent tax. ${ }^{46}$

Prior to 2012, Apple Sales International was also a shell company with no employees. In 2012, 250 employees were transferred to Apple Sales International from another of Apple's Irish entities, thus

25 making it appear as though Apple Sales International has a substantial business purpose.

The overall flow of income is as follows. A third party manufacturer in a country such as China is contracted by Apple Sales International to manufacture the products. The finished products are

30 then sold to Apple Sales International, who on-sell the products to Apple Distributions International or Apple Singapore for distribution around the world. Apple Distributions International and Apple Singapore pay a high price for these products, as the profits they receive from product sales are significant. Apple Sales International 35 therefore has a substantial income, which is transferred to Apple Operations Europe in the form of dividends. The dividends are then

\footnotetext{
${ }^{43}$ Levin and McCain, above n21, at 20.

${ }^{44}$ Levin and McCain, above n 21, at 22.

${ }^{45}$ For an explanation of the Irish Corporate Residency rules, refer to section B of this part of the paper.

${ }^{46}$ Sokatch, above $\mathrm{n} 4$, at 726.
} 
transferred to Apple Operations International in the form of further dividends. $^{47}$

Setting up subsidiaries in this way exploits a key difference in the Irish and United States tax bases. For Irish purposes, Apple Operations International is not an Irish resident because Irish residency rules are based on a system of management and control. The company is disregarded for United States tax purposes as the United States tax residency rules are based on place of incorporation. United States law provides that a shell entity that is incorporated in a 10 foreign jurisdiction can be disregarded if the extent of control by the parent company is such that the shell entity is a mere instrument of the parent. $^{48}$

Shifting the business in this manner enables offshore sales revenue to be generated in Ireland rather than in the United States. In the

15 1990s manufacturing was outsourced to third parties, ${ }^{49}$ meaning that Apple Sales International contracts to become the first purchaser of the goods from the manufacturers. The goods are then sold to the relevant distribution subsidiary at a much higher price than they were purchased for. ${ }^{50}$

20 Apple Sales International is the primary intellectual property rights recipient from Apple Inc. Both licensing agreements and cost sharing agreements are used to shift intellectual property rights offshore. ${ }^{51} \mathrm{~A}$ cost sharing agreement is where two or more related entities share the cost of developing the intellectual property, and then share the

25 resulting rights. The subsidiary will typically make a buy-in payment to compensate the parent company for their loss for incurring initial costs and risks in development. ${ }^{52}$

Offshore profit shifting is enabled by these agreements for two key reasons. First, the proportion of profits that remains out of the United

30 States is not an accurate reflection of the proportion of research and development that is done within the United States. ${ }^{53}$ Despite the

\footnotetext{
${ }^{47}$ Levin and McCain, above n21, at 26.

${ }^{48}$ Levin and McCain, above n 21, at 23.

${ }^{49}$ Levin and McCain, above n 21 at 19

${ }^{50}$ Levin and McCain, above $\mathrm{n} 21$, at 19.

${ }^{51}$ Levin and McCain, above n 21 at 7.

${ }^{52}$ Levin and McCain, above $\mathrm{n} 21$ at 8.

${ }^{53}$ From 2009-2012, ASI made USD 74 billion in profits from the intellectual property covered by the cost sharing agreements, yet payments of only USD 5 billion were made to Apple Inc in relation to the research and development. See Levin and McCain, above n 21, at 28-29.
} 
majority of the research being done in the United States, ${ }^{54}$ the bulk of the profits are stored offshore. Secondly, the transfer of rights does not result in any change to the commercial operations of the company. They simply alter the tax liability in regard to the profits. ${ }^{55}$ One would expect that if there were a commercial reason behind the transfers, there would also be comparable transfers to other regions where Apple conducts business. The fact that there are not indicates that the tax benefits are the predominant purpose of the transactions. ${ }^{56}$

\section{Intellectual Property}

10 The scope of this paper will be confined to a discussion of the use of the Dutch Sandwich and Double Irish tax structures to avoid paying tax on transactions involving intellectual property assets. While it is feasible that the Double Irish and Dutch Sandwich could also be applicable to physical, tangible goods, one of the reasons these

15 structures are so effective is that the assets in question, namely the intellectual property, can be instantly transferred between jurisdictions, and it is easy to exploit their value. ${ }^{57}$

For the purposes of this paper, intellectual property will be taken to mean copyright, patents and trade marks. ${ }^{58}$ Patents are granted in 20 respect of inventions, ${ }^{59}$ and are therefore at the heart of the structures used by technology-based companies such as Google and Apple. The paper will largely focus on the use of patents because they are the most commonly used rights transferred in the Double Irish and Dutch Sandwich transactions. ${ }^{60}$

\footnotetext{
${ }^{54}$ Information supplied to the Senate Permanent Subcommittee by Apple indicated that in 2011, 95\% of research and development was conducted in the United States. See Levin and McCain, above n 21, at 28.

${ }^{55}$ Levin and McCain, above n 21, at 28.

${ }^{56}$ Levin and McCain, above n 21, at 29.

${ }^{57}$ W Wesley Hill and J Sims Rhyne "Opening Pandora's Patent Box: Global Intellectual Property Tax Incentives and Their Implications for The United States" (2013) 53(3) IDEA - The Intellectual Property Law Review 371 at 373.

${ }^{58}$ Copyright protection lends itself to literary and artistic works, while trade marks protect both the goodwill and the symbols of a company that are needed to distinguish competing products and services.

${ }^{59}$ William Cornish, David Llewelyn and Tanya Aplin Intellectual Property: Patents, Copyright, TradeMarks and Allied Rights (7th ed, Sweet \& Maxwell, London, 2010) at $1-05$.

${ }^{60}$ Howard Gleckman “The Real Story On Apple's Tax Avoidance: How Ordinary It Is" (21 May 2013) <www.forbes.com>.
} 


\section{A Characteristics of Intellectual Property}

Intellectual property rights are typically conferred through statute, ${ }^{61}$ and have two key features that help to explain why intellectual property is the favoured subject matter for the tax avoidance strategies at issue in this paper. First, intellectual property rights are traditionally exclusive rights rather than absolute rights. ${ }^{62}$ The rights given are therefore the right to exclude another from using your property, rather than a positive right to use the property. Secondly, intellectual property is intangible. Despite being intangible, it will

10 typically be treated in the same manner as all other property. ${ }^{63}$ Thus, when you have an intellectual property right you can keep the rights, assign them to someone else, grant exclusive or non-exclusive licences to use the property, and you can abandon your rights. ${ }^{64}$

The ability to licence intellectual property is at the heart of the tax avoidance issue. Provisions allowing the licensing of intellectual property rights are put in place to cater for the common circumstance where the licensee is in a better position to exploit the rights provided than the rights holder. ${ }^{65}$ Thus, the overseas transfer of rights is facilitated in order to promote cheaper manufacturing of goods. The

20 strong protection of intellectual property rights in the United States means that many licences will only cover the economic part of the bundle of rights. ${ }^{66}$ By licensing only some of the rights, the United States based rights holder is able to retain the strong rights protections granted in the United States, while shifting economic rights and

25 profits offshore to avoid United States corporate income tax.

Additionally, intellectual property assets are also unique. Tangible assets are typically similar to other tangible assets, and thus are relatively easy to value. Conversely, intangible assets are often different to other assets and are therefore difficult to value accurately

\footnotetext{
${ }^{61}$ In New Zealand, the Copyright Act 1994, the Patents Act 1953, and the Trade Marks Act 2002. Note that in 2014 the Patents Act 2013 will come into force replacing the Patents Act 1953.

62 Philip W Grubb and Peter R Thomsen Patents for Chemicals, Pharmaceuticals, and Biotechnology: Fundamentals of Global Law, Practise and Strategy (5th ed, Oxford University Press, New York, 2010) at 4.

${ }^{63}$ Grubb and Thomsen, above n 62, at 6.

${ }^{64}$ Grubb and Thomsen, above $\mathrm{n} \mathrm{62,} \mathrm{at} \mathrm{6.} \mathrm{This} \mathrm{collection} \mathrm{of} \mathrm{property} \mathrm{rights} \mathrm{is}$ collectively referred to as the bundle of rights. That is, that property rights in both tangible and intangible things are rights in relation to others, rather than rights to the thing. The bundle of rights enables divisibility of ownership and separation of different rights. Thus, it is possible to license part of the rights associated with a patent, and retain the other rights. See Denise R Johnson "Reflections on the Bundle of Rights" (2007) 32 Vt L Rev 247 at 247.

${ }^{65}$ Cornish, Llewelyn and Aplin, above n 59, at 7-22.

${ }^{66}$ Levin and McCain, above n 21, at 25.
} 
because a comparison cannot be made. In regard to patents, this uniqueness arises because the property right must be in relation to an invention that is both novel and involves an inventive step. ${ }^{67}$

From the above it can be seen that the intangible nature of

5 intellectual property gives it two key advantages for involvement in tax avoidance schemes. First, its intangible nature means the rights can be shifted almost instantly, and secondly its uniqueness and the corresponding difficulties in valuation make it significantly easier to exploit pricing arrangements.

\section{Are These Transactions Problematic?}

Use of the Double Irish and Dutch Sandwich structures gives two key results for the companies and States involved. First, they enable companies such as Google and Apple to avoid the relatively high corporate income tax rate in the United States. This results in these

15 corporations paying income tax at rates that amount to as little as $2.4 \%$ of their profits. ${ }^{68}$ The second result of shifting significant profits overseas is that there is little connection between where the economic activity takes place and where the profits are booked. ${ }^{69}$ These results lead to two problems for states. There is a negative effect on the

20 economy as a result of shifting profits to jurisdictions where they are tax free, and there is a concern that allowing the shifts of intellectual property is inconsistent with the rationale for providing intellectual property protection in the first place.

\section{A Economic Effects}

25 The economic activity can be separated into two categories. They are the development of the intellectual property such as trade marks and patents, and the product sales. The intellectual property involved in these transactions will typically be developed in the United States, resulting in economic activity there from job creation and resource

30 use. The intellectual property will also be protected in the United States through patent or trade mark applications and grants. By contrast, the product sales and their resulting economic activity will take place in Ireland.

As a result of employing the Double Irish and Dutch Sandwich

35 structures Google were able to avoid tax of up to USD 2 billion in the

\footnotetext{
${ }^{67}$ Patents Act 1953, s 21(1).

${ }^{68}$ Loomis, above n 20, at 828 .

${ }^{69}$ Fryer, above n 34.
} 
United States by shifting billions of dollars of profits to overseas tax havens. ${ }^{70}$ This is clearly a significant blow to the government's reliance on tax collection. ${ }^{71}$ The economic effect of tax avoidance is further emphasised by the fact that "corporate tax receipts as a share

5 of profits are at their lowest level in at least 40 years". ${ }^{72}$ The United States has one of the highest corporate tax rates in the Organisation of Economic Co-operation and Development (OECD), and corporate profits now form a record high percentage of GDP. Despite this domination of the economy by corporations, corporate tax now forms

10 a record low percentage of federal taxes. ${ }^{73}$ This is taking place against a background of record levels of federal debt, which has in 2013 reached around USD 16 trillion. ${ }^{74}$

The extent of the problem becomes clearer when the link between intellectual property and growth of the national economy is examined.

15 It is clear that there is a causal link between intellectual property and economic growth, and that intellectual property resources are now necessary in order to be competitive on an international scale. ${ }^{75}$ The importance of intellectual property to economic growth reflects the sheer scale of intellectual property use, thus indicating that the role of

20 tax derived from intellectual property should also be quite significant.

The structures also provide multinational corporations with an advantage over United States based domestic corporations. ${ }^{76}$ While many corporations are now multinational, the smaller national companies are at a disadvantage because they do not have the 25 resources to engineer tax avoidance structures. Thus, the companies that are already the most profitable are the ones who are able to exploit loopholes in the tax law in order to make them even more profitable.

\footnotetext{
${ }^{70}$ Fryer, above $\mathrm{n} 1$.

${ }^{71}$ It is a generally accepted premise that the Government relies on income tax to function effectively. See VanDenburgh, above n 2, at 315.

${ }^{72}$ Damian Paletta "With Tax Break, Corporate Rate is Lowest in Decades" (3 February 2012) Wall Street Journal <online.wsj.com>.

${ }^{73}$ Fryer, above $\mathrm{n} 1$. There is evidence that the share of corporate tax revenue as a percentage of GDP is consistently decreasing across the OECD. See Simon Loretz "Corporate Taxation in the OECD in a Wider Context" (2008) 24 Oxford Review of Economic Policy 639 at 642, Figure 1.

${ }^{74}$ Levin and McCain, above $\mathrm{n} 21$, at 3

75 Donald S Chisum and others Principles of Patent Law: Cases and Materials (2nd ed, Foundation Press, New York, 2001) at 59.

${ }^{76}$ Levin and McCain, above n 21, at 10.
} 
B Consistency with the Rationale for Protecting Intellectual Property

The key justification for protection of intellectual property, in particular patents, is the incentive to invent theory. Under this theory, patents are granted to encourage invention. Without being certain that there is some kind of protection for their work and thus an ability to make money from it, people are less likely to engage in the inventive process. ${ }^{77}$ In this respect, patent protection is a bargain between the inventor and the public. That is, the law provides protection for inventions and exclusive rights that enable profits to be derived from the invention, in return for a public disclosure of the invention and its contents by the inventor. ${ }^{78}$ This provides a benefit to society from access to the invention, albeit at a cost, while also providing a benefit to the inventor in the form of remuneration.

15 When intellectual property is licensed overseas and the related profits are derived overseas, there is a lack of connection between the state providing the incentive and protection and the state where the profits reside. Protection of intellectual property by the state generally confers an economic benefit back to the state both in terms of creation

20 of economic activity and in terms of the ability to tax profits. When the profits are being made and half the economic activity is taking place overseas, the benefit that the state ought to receive in return for protecting the intellectual property and providing the incentive to do the work does not occur on the level that it should.

25 To a certain extent, profit shifting and overseas licensing can also be seen as an abuse of the privilege provided by intellectual property rights. Protection of intellectual property provides the rights holder with a limited form of monopoly, in that they have control over the market for their particular goods or services. ${ }^{79}$ This is an exception to

30 the general rule against monopolies. The privilege of being provided with rights is being abused in order to obtain tax benefits.

V Could the New Zealand GAAR Catch These Types of Strategies?

Considering that the Double Irish and Dutch Sandwich structures have

35 such serious consequences, the remaining sections of the paper will be given over to consideration of possible methods to counteract them.

${ }^{77}$ Chisum and others, above $\mathrm{n} 75$, at 59 .

${ }^{78}$ Chisum and others, above $\mathrm{n} 75$, at 3 .

${ }^{79}$ Grubb and Thomsen, above n 62, at 7 . 
This part of the paper will consider whether a GAAR in the form of the New Zealand rule could be used to counteract the Double Irish and Dutch Sandwich transactions. The parent company and the subsidiaries will be considered separately.

\section{A Income Tax Act 2007}

The New Zealand GAAR is formed by a combination of several legislative provisions, namely ss YA 1 , BG 1 and GA 1 of the Income Tax Act 2007. The overarching rule is that "a tax avoidance arrangement is void as against the Commissioner for income tax 10 purposes." 80 Tax avoidance is then further defined in s YA 1 as including:

(a) directly or indirectly altering the incidence of any income tax: pay income tax or from a potential or prospective liability to future income tax:

(c) directly or indirectly avoiding, postponing, or reducing any liability to income tax or any potential or prospective liability to future income tax

A transaction is considered to be an avoidance arrangement if it has "tax avoidance as one of its purposes or effects", making it clear that tax avoidance does not have to be the sole reason for undertaking the 25 arrangement. ${ }^{81}$ The final provision comprising the GAAR is s GA 1, which defines the Commissioner's powers to act when an arrangement is found to be an avoidance arrangement.

Importantly, the definition of avoidance is not exhaustive, so schemes that do not fit directly into this definition can also be caught if

30 the courts deem them to be avoidance arrangements.

\section{B Judicial Interpretation and Application of the GAAR}

The broad wording of the GAAR means that it has a conceivably wide scope that must be confined by the courts. When taken literally, the GAAR would apply to the majority of business and family

35 transactions. ${ }^{82}$ As a result of the potential scope of the provision, a purposive interpretation will be preferred to the literal reading of the

\footnotetext{
${ }^{80}$ Income Tax Act 2007, s BG 1(1).

${ }^{81}$ Income Tax Act 2007, s YA 1.

${ }^{82}$ See for example Elmiger $v$ Commissioner of Inland Revenue [1966] NZLR 683 per Woodhouse J.
} 
provisions. ${ }^{83}$ A purposive interpretation is consistent with s 5(1) of the Interpretation Act 1999, which instructs the courts to determine the meaning of an enactment in the light of both the text and its purpose. ${ }^{84}$

Before applying the GAAR, it will be necessary to consider whether the transactions are actually covered by the specific provision at issue. If the transactions are not in accordance with the letter of the law, there will be no need to contemplate whether the GAAR could be used to remedy the situation. ${ }^{85}$ In situations where the relevant arrangement or structure is in accordance with the strict letter of the law, consideration will move to whether the "taxpayer has use[d] specific provisions of the Act and otherwise legitimate structures in a manner which cannot have been within the contemplation of Parliament." 86 This is known as the parliamentary contemplation test.

The leading case describing application of the GAAR is the Supreme

15 Court ruling in Ben Nevis Forestry Ventures Ltd \& Others $v$ Commissioner of Inland Revenue (Ben Nevis). ${ }^{87}$ In that case, the Supreme Court endorsed the three-step test for application of the GAAR. ${ }^{88}$ The preliminary step before the GAAR can be considered is to determine whether the transactions at issue comply with the strict letter 20 of the law, as the GAAR can only apply when the transactions are beyond the scope of what Parliament intended the law to be used for. ${ }^{89}$ If the transactions are determined to fall within the letter of the law, the three-stage application of the GAAR can proceed.

The first step is for the court to determine whether there was an 25 arrangement. ${ }^{90}$ An arrangement is defined in s YA 1 to mean "any contract, agreement, plan or understanding". It is clear that the concept of arrangement covers both the initial setting up of the transactions and their working on a regular basis. ${ }^{91}$

\footnotetext{
${ }^{83}$ See for example BNZ Investments Ltd v Commissioner of Inland Revenue (2000) 19 NZTC 15,732 (HC) at [46]; Commissioner of Inland Revenue v Gerard [1974] 2 NZLR 279 at 280 (CA); Challenge Corporation v Commissioner of Inland Revenue (1986) 2 NZLR 513 at 534 (CA).

${ }^{84}$ Interpretation Act 1999, s 5(1).

${ }^{85}$ Ben Nevis Forestry Ventures Ltd \& Ors v Commissioner of Inland Revenue [2008] NZSC 115, [2009] 2 NZLR 289 at [106].

${ }^{86}$ Penny v Commissioner of Inland Revenue [2011] NZSC 95 at [47].

${ }^{87}$ Ben Nevis, above n 85.

${ }^{88}$ Ben Nevis, above n 85, at [160].

${ }^{89}$ Ben Nevis, above $\mathrm{n} 85$, at [106].

${ }^{90}$ Ben Nevis, above $\mathrm{n} 85$, at [160].

${ }^{91}$ Penny v Commissioner of Inland Revenue, above n 86, at [34]..
} 
The second step is for the court to determine the purpose of the arrangement. ${ }^{92}$ This involves the application of the definition in s YA 1. A tax avoidance arrangement is defined as: ${ }^{93}$ affected by the arrangement or by another person, that directly or indirectly -

(a) has tax avoidance as its purpose or effect; or

(b) has tax avoidance as 1 of its purposes or effects, whether or not any other purpose or effect is referable to ordinary business or family dealings, if the tax avoidance purpose or effect is not merely incidental

The arrangement is assessed objectively, without specifically looking 15 at the motives of those who enter into the arrangement. ${ }^{94}$ If the transaction is not motivated by a legitimate, non-tax purpose, the Commissioner is able to assert it is part of a tax avoidance arrangement. ${ }^{95}$

Application of the parliamentary contemplation test will occur at 20 this second stage. As the majority in Ben Nevis stated, the function of the GAAR is to "prevent uses of the specific provisions which fall outside their intended scope in the overall scheme of the Act." 96 Therefore, the key question is whether the arrangement, when viewed in a commercially and economically realistic way, is using the relevant provision in a way that is consistent with Parliament's purpose. ${ }^{97}$

The final step will be to determine whether the Commissioner will use his powers of reconstruction in s GA 1 to adjust the arrangement. ${ }^{98}$ When an arrangement is held to be void as against the Commissioner under s BG 1, the Commissioner has the power to adjust the taxable 30 income of a person involved in the arrangement in order to counteract the tax advantage gained by use of the arrangement. ${ }^{99}$

There is no definition for the phrase tax advantage in the legislation, meaning that the case law will influence the Commissioner's decision.

\footnotetext{
92 Ben Nevis, above n 85, at [162].

${ }^{93}$ Income Tax Act 2007, s YA 1. Emphasis added.

${ }^{94}$ Ben Nevis, above $\mathrm{n} 85$, at [102].

${ }^{95}$ Penny $v$ Commissioner of Inland Revenue, above n 86, at [49]. See also Ben Nevis, above n 85, at [109].

${ }^{96}$ Ben Nevis, above n 85, at [106].

${ }^{97}$ Ben Nevis, above n 85, at [109]. The Supreme Court in Penny again emphasised the importance of the commercial reality and the motivation behind the transaction. See Penny v Commissioner of Inland Revenue, above n 86, at [49].

98 Income Tax Act 2007, s GB 1.

${ }^{99}$ Ben Nevis, above n 85, at [169].
} 
The decision in Ben Nevis appears to suggest that there must be a link between the tax advantage and the obtaining of a tax benefit beyond those contemplated by Parliament. ${ }^{100}$ For the purposes of s BG 1, the tax advantage will not encompass all tax advantages, but will be limited to the tax advantages that would have been obtained if the GAAR were not applied. In Miller (No. 1) v Commissioner of Inland Revenue (Miller), Baragwanath $\mathrm{J}$ noted that tax advantage "must include the benefit of tax avoidance which (but for [the GAAR]) the Commissioner was entitled to conclude the plaintiffs have

10 achieved". ${ }^{101}$ In concurrence with the High Court, Blanchard J for the Court of Appeal noted that "the Commissioner is not inhibited from looking at the matter broadly and making an assessment on the basis of the benefit directly or indirectly received by the taxpayer". ${ }^{102}$

The Commissioner's powers of adjustment are broad and

15 discretionary. If the taxpayer disagrees with the adjustment made, the onus will be on the taxpayer to establish that it was wrong, and by how much. ${ }^{103}$ If the taxpayer cannot demonstrate clearly what the correct reconstruction ought to be, the Commissioner's view will prevail. ${ }^{104}$ The taxpayer can establish what they think the correct reconstruction 20 ought to be by submitting an alternative reconstruction or adjustment. ${ }^{105}$ When making the adjustment, the Commissioner does not have to create an alternative scheme or attempt to determine what other steps may have been available to the taxpayer. ${ }^{106}$ Rather, the Commissioner must simply ensure that the taxpayer does not gain a tax

25 advantage from the arrangement. ${ }^{107}$

The provision of a broad discretion to the Commissioner means that the courts will typically be reluctant to intervene and alter the reconstruction made by the Commissioner. ${ }^{108}$ The discretion must simply be exercised in good faith and free from irrelevant 30 considerations.

\footnotetext{
${ }^{100}$ Ben Nevis, above n 85, at [169]-[171].

${ }^{101}$ Miller (No. 1) v Commissioner of Inland Revenue (1997) 18 NZTC 13.001 at 13,035 (HC). Note that the decision of Baragwanath $\mathbf{J}$ was upheld in the Pricy Council, see Miller v Commissioner of Inland Revenue [2001] 3 NZLR 316 (PC).

${ }^{102}$ Miller v Commissioner of Inland Revenue [1999] 1 NZLR 275 at 279 (CA).

${ }^{103}$ New Zealand Master Tax Guide 2012 at 33-125.

${ }^{104}$ Ben Nevis, above n 85, at [171].

105 Ben Nevis, above n 85 at [171].

${ }^{106}$ Case W33 (2004) 21 NZTC 11,321 at [48].

107 Case W33, above n 106, at [48].

108 Peterson v Commissioner of Inland Revenue (No 2) (2002) 20 NZTC 17,761 at [70] (HC).
} 


\section{Hypothetical Application of the GAAR to the Parent Company}

The GAAR could not be used to counteract the structures as a whole, as multiple cross-border transactions are involved in the arrangement, and domestic law could not hope to reach all relevant countries. It is also clear that avoidance of foreign tax will not be sufficient to activate the GAAR, as tax in this context is taken to mean New Zealand tax. ${ }^{109} \mathrm{In}$ the light of these difficulties, the paper will consider first whether the parent company' statement of income would be vulnerable to a GAAR in the New Zealand form. Application of the GAAR to the subsidiaries

10 will be considered separately.

\section{$1 \quad$ Compliance with the Specific Provisions at Issue}

Taking the Dutch Sandwich structure described in part II; the parent company receives income from local sales and use of the intellectual property, and also from the low royalty payments received from

15 licensing the intellectual property to the subsidiary. ${ }^{110}$ This is the only transaction that the parent company is involved in. The licence payments were typically structured to be as low as possible in order to reduce the income tax payable by the parent company. The payments in question fall within the following definition of a transfer pricing agreement set out in s GC 6:111

(2) An arrangement is a transfer pricing arrangement if -

(a) the arrangement involves the supply and acquisition of goods, services, money, other intangible property, or anything else; and

(b) the supplier and acquirer are associated persons; and

(c) the arrangement is a cross-border arrangement under subsection (3).

30 The consequence of being deemed to be transfer pricing arrangements is that the payments must be made in accordance with the arm's length principle. That is, the arrangement must be made as if the buyer and the seller were unrelated economic entities. ${ }^{112}$

In s GB 2 there is a specific-anti avoidance provision governing the misuse of transfer pricing. This section would be applicable where the pricing was not found to reflect the arm's length principle. In the

\footnotetext{
${ }^{109}$ Inland Revenue Interpretation Statement: Tax Avoidance and the Interpretation of sections BG 1 and GA 1 of the Income Tax Act 2007 (13 June 2013) at [544].

${ }^{110}$ Royalties are generally to be treated as income, for example in New Zealand under s CC 9 of the Income Tax Act 2007.

111 Income Tax Act 2007, s GC 6(2).

112 Income Tax Act 2007, s GC 8.
} 
alternative, if the specific rule could not apply, or did not apply in a satisfactory manner, it is possible the GAAR could be used. ${ }^{113}$ For application of the GAAR to occur, the specific transfer pricing provisions in s GC 6 must be satisfied. ${ }^{114}$ This may occur even in artificial transfer pricing arrangements because the nature of intellectual property is such that it is difficult to place an accurate value on it. ${ }^{115}$ Thus, the potential for the rules to be exploited is much higher than with other goods.

The difficulties with applying the arm's length rule to these types of 10 transactions arise because it is easy to exploit the value of the assets. The onus is on the taxpayer to determine the arm's length amount, ${ }^{116}$ meaning the party determining the arm's length price is the party that has the most intricate knowledge of the true value of the assets. This makes it easier for the taxpayer to make an argument that the arm's 15 length principle has been satisfied because they can easily misrepresent the true value of the assets. Any arguments made here would clearly be very fact specific, and would ultimately be difficult to determine.

If the Commissioner were to bring a case against a taxpayer in respect of a transfer pricing agreement, they could make two possible

20 arguments. First, the Commissioner can argue that the strict wording of the provisions in regard to transfer pricing have not been complied with, in which case the Inland Revenue Department can challenge the taxpayer's statement of their income.

Application of the arm's length principle to the licence agreement 25 between the parent company and subsidiary B would result in a slight increase in the income of the parent company. After application of the arm's length principle, significant profits will still remain offshore and beyond the reach of the tax authorities.

Alternatively, if it could be shown that the wording of the arm's 30 length provision was complied with, the Commissioner can bring a case under the GAAR.

$2 \quad$ Step 1: Was there an Arrangement?

The first step in the application of the GAAR will be to determine whether there was an arrangement. ${ }^{117}$ There are two possible options

\footnotetext{
113 See for example Challenge Corporation $v$ Commissioner of Inland Revenue [1986] 2 NZLR 513 at 559 (PC).

${ }^{114}$ Ben Nevis, above n 85, at [109].

115 See the above discussion in Part III in relation to the characteristics of intellectual property.

116 Income Tax Act 2007, s GC 13(4).

${ }^{117}$ Ben Nevis, above n 85, at [160].
} 
when defining the arrangement. It can be defined broadly as including the entire Double Irish and Dutch Sandwich schemes, or it can be defined narrowly as the initial licensing transaction from the parent company to subsidiary B. When defined as meaning the scheme as a whole, the arguments following are stronger, as it is the entirety of the scheme that enables the tax avoidance to take place. For the purposes of applying the GAAR to the parent company, the arrangement in question will be the entirety of the Double Irish and Dutch Sandwich structures. That is, it will include the plan to license the intellectual

10 property to specifically set up subsidiaries, and the royalty payments and transfers. It is thus clear that there is an arrangement within the definition of s YA 1.

3 Step 2: Is the Purpose of the Arrangement within Parliamentary Contemplation?

15 In the Double Irish and Dutch Sandwich structures, setting royalty fees artificially low and setting up shell companies has no benefit to the parent company aside from reducing its income tax bill. This indicates that the definition of tax avoidance in S YA 1 is likely to be satisfied.

The second step is to determine the purpose of the arrangement, ${ }^{118}$

20 and whether it sits outside the scope of the specific rule, as intended by Parliament. ${ }^{119}$ That is, was the principle used in a manner that was within parliamentary contemplation. This will involve consideration of the commercial and economic reality of the situation, as well as of features of the whole arrangement. ${ }^{120}$

25 The purpose behind enactment of transfer pricing rules was to ensure that the proper amount of income derived by a multinational is attributed to its New Zealand operations. ${ }^{121}$ When independent enterprises deal with each other, their dealings are generally determined by external market forces. By contrast, dealings between related entities can be driven by other factors such as internal profitability and the allocation of those profits. ${ }^{122}$ Regulation of dealings between related entities was introduced to ensure that transfer

\footnotetext{
118 Note that Supreme Court in Glenharrow Holdings Ltd v Commissioner of Inland Revenue emphasised that it is the purpose of the arrangement that is to be determined, not the purpose of the parties. The purpose or effect of the arrangement is to be determined objectively. See Glenharrow Holdings Ltd v Commissioner of Inland Revenue [2008] NZSC 116, [2009] 2 NZLR 359 at [38]. Also emphasised in Ben Nevis, above n 85, at [102].

${ }^{119}$ Ben Nevis, above n 85, at [162].

${ }^{120}$ Ben Nevis, above n 85, at [109].

${ }^{121}$ Inland Revenue Tax Information Bulletin (Vol 12, No 10, October 2000).

${ }^{122}$ Inland Revenue Tax Information Bulletin, above n 121 at [41].
} 
pricing arrangements were not used to shift goods and services between states in order to obtain maximum tax benefits for both entities. It is highly unlikely that using entities specifically designed to engineer tax avoidance is within parliament's contemplation of what constitutes an allowed transfer pricing agreement.

The Double Irish and Dutch Sandwich arrangements are set up to facilitate tax avoidance in cross-border transactions between related entities. The commercial and economic reality is that the arrangement appears to have no substantial business purpose other than tax

10 avoidance, and the schemes appear to be artificial and contrived. However, any analysis of the parliamentary contemplation test is highly fact specific. ${ }^{123}$ In the case of Apple, the clear separation of its United States based income and its offshore income might provide a foundation for an argument that there was a substantial business

15 purpose in the arrangement. If Apple had shifted all of its income offshore the arrangement would appear to be more contrived in comparison to just shifting the overseas income.

This step of the analysis indicates that application of the GAAR to the parent company will hold up better where the arrangement was 20 broadly defined. The argument that there was a tax avoidance arrangement is stronger when you can show a series of transactions that give multiple overall benefits, rather than a single exploitation of the transfer pricing rules that might be difficult to categorise as tax avoidance. It is possible to argue that the single licensing agreement is

25 an exploitation of the transfer pricing rules and beyond parliament's contemplation of the use of those rules, but the argument that this also equates to tax avoidance is more difficult.

A further argument that could be made in relation to the purpose of the arrangement concerns the extent of the tax avoidance undertaken.

30 Eichelbaum CJ in Hadlee v Commissioner of Inland Revenue noted that on the particular facts of the case, "[t]he potential tax benefits were too significant and obvious."124 This statement formed part of an analysis that concluded "that it would require a considerable degree of naivety to conclude that [the tax benefits] played merely an incidental 35 part in the scheme." The indication that can be drawn from this is that

\footnotetext{
${ }^{123}$ This is illustrated by the detailed ruling in Alesco where the relevant provisions and transactions were considered in great depth. See Alesco New Zealand Ltd $v$ Commissioner of Inland Revenue [2013] NZCA 40.

${ }^{124}$ Hadlee v Commissioner of Inland Revenue [1989] 2 NZLR 447 (HC) at 470. Note that the High Court decision of Eichelbaum CJ was upheld in the Court of Appeal: Hadlee v Commissoner of Inland Revenue [1991] 3 NZLR 517 (CA).
} 
in some situations, the extent of the tax avoidance may be an indicator of a tax avoidance purpose. This argument is strengthened by Harrison J's recognition in Westpac Banking Corporation $v$ Commissioner of Inland Revenue (Westpac) that: ${ }^{25}$

The disparity between the underlying economics of the transaction and the resulting taxation treatment confirms that the anticipated tax effect was the true purpose of the transaction.

In the Double Irish and Dutch Sandwich, there is a clear disparity between the underlying economics of the transaction and the resulting tax treatment. The tax benefits are also significant, indicated by reports that Google saves up to USD 2 billion each financial year. ${ }^{126}$

15 An argument such as this might strengthen the Commissioner's case that the tax avoidance purpose was more than merely incidental.

There are several difficulties evident in arguing that the GAAR could be applied to negate the tax benefits received by the parent company. Analysis of these difficulties reveals a fundamental problem facing

20 revenue authorities. The multitude of rules involved and the crossborder nature of the transactions means it is often possible to get a remedy in relation to a single transaction, but that it will be difficult to break down the Double Irish and Dutch Sandwich schemes as a whole.

\section{Reconstruction}

Step 3: Application of the Commissioner's Powers of

The final step in application of the GAAR to the parent company is the determination of the Commissioner's powers of reconstruction. The Commissioner has the power to adjust the taxable income of a person affected by the arrangement in order to counteract the tax advantage obtained from the arrangement. ${ }^{127}$ Here, the Commissioner has an extremely broad discretion as they may make any adjustments they think appropriate. ${ }^{128}$

Application of the Commissioner's powers of reconstruction to the subsidiaries is not limited to the specific transaction that the parent 35 company is involved in. As was stated by Harrison $\mathrm{J}$ in Westpac, "the Commissioner is not bound to isolate out and counteract only

125 Westpac Banking Corporation v Commissioner of Inland Revenue CIV 2005404-2843 at [597].

126 Sokatch, above n 4, at 726.

127 Income Tax Act 2007, s GA 1(2).

${ }^{128}$ Alesco New Zealand Ltd v Commissioner of Inland Revenue, above n 123, at [119]. 
particular elements giving rise to a tax advantage", meaning that the Commissioner can view the scheme as a whole. ${ }^{129}$ Similar to the benefits obtained in Westpac, the tax benefits of the Double Irish and Dutch Sandwich would not be gained through use of the individual transactions. Rather, it was the scheme as a whole that provided the tax benefit. ${ }^{130}$

The practical difficulty with the application of the Commissioner's power is that the profits are sitting offshore and are difficult for the Commissioner to assess. The initial power to make a reconstruction

10 belongs to the Commissioner. However, if the taxpayer disagrees with the Commissioner's assessment, the taxpayer has the onus of establishing that it is wrong, and by how much. ${ }^{131}$ Given the difficulty of determining the value of the assets in question, it is unlikely to be easy for the taxpayer to establish that the Commissioner was wrong.

15 D Hypothetical Application of the GAAR to the Subsidiaries This section will consider whether a tax return made by any of the two or three subsidiaries would be upheld in the presence of a GAAR in the form of the New Zealand rule. For the purposes of this section it will be assumed that all income tax legislative requirements are strictly 20 complied with. As with the application of the GAAR to the Parent company, the first step is easily satisfied and there is an arrangement. The arrangement is again defined widely to mean the scheme as a whole, including the setting up and use of shell companies, the overall effect of profit shifting and exploitation of transfer pricing agreements.

25 In the Double Irish structure described above, the use of the second subsidiary has no economic purpose other than to avoid paying taxes. The consequence is that utilisation of tax havens and shell companies will make it difficult for companies to establish that tax avoidance was not one of the purposes or effects of the arrangement. Even if the

30 taxpayer can establish that they had a substantial business purpose for the arrangement, it is unlikely that a court would rule that the tax benefit was merely incidental.

In the case of the subsidiaries, it is difficult to see how an argument could succeed that the arrangement has a substantial business purpose.

35 The transactions between the Irish subsidiaries have no purpose other

\footnotetext{
${ }^{129}$ Westpac Banking Corporation v Commissioner of Inland Revenue, above n 125, at [641].

${ }^{130}$ See for example, Westpac Banking Corporation $v$ Commissioner of Inland Revenue, above n 125, at [641].

${ }^{131}$ Ben Nevis, above n 85, at [171].
} 
than avoiding tax. It is clear that a single company could conduct the business conducted by the Irish subsidiaries. The second company is simply acting as a vehicle that enables the funds to be transferred in a manner that is not caught by United States law. For this reason, it is arguably clearer that the subsidiary companies are engaged in a tax avoidance arrangement than the parent company. The separation by the parent company of its local sales and overseas sales gives a plausible explanation for the shifting of business to an offshore subsidiary. No such reason exists to explain the payments that occur between the Irish subsidiaries.

It is clear that in the case of companies such as Google and Apple there is an existing company structure that handles any income and financial issues. These structures are in place to deal with all local sales, as in the Double Irish and Dutch Sandwich structures it is only

15 the overseas sales that are handled by the subsidiaries. It is difficult to argue that tax avoidance was not a purpose or effect if there is an existing mechanism for handling profits and payments of income tax that could be used for overseas sales in addition to any local sales.

The final consideration when applying the GAAR is the powers of 20 the Commissioner to counteract the arrangement. This is the most difficult part of the analysis, as the Double Irish and Dutch Sandwich would be likely to fall within the scope of the GAAR, but it is not clear whether the Commissioner would have the ability to do anything about them in a practical sense.

25 In order to apply the GAAR to the subsidiaries, the Commissioner would have to argue that the assessable income is the income from all overseas sales, and that this should be attributed to subsidiary S. Assuming that subsidiary B remains a resident of an overseas tax haven, it is the income of subsidiary $S$ that would be in question. In 30 order to accurately use their powers of reconstruction, the Commissioner would need to determine the income from sales and use of intellectual property by subsidiary $\mathrm{S}$, and use this as the figure for determining the income tax bill. This is more straightforward than the determination of the parent company's income as the company in 35 question is receiving income in the jurisdiction, so the Commissioner would simply need to look at income before the deductions were claimed. This is permissible because the deductions claimed were not within parliamentary contemplation owing to their role in the tax avoidance arrangement. 


\section{Why has the United States GAAR Not Been Applied?}

This paper concludes that a GAAR in the form of the New Zealand rule would possibly find the Double Irish and Dutch Sandwich arrangements to be tax avoidance, and therefore void for tax purposes.

5 There would however, be practical difficulties in using the Commissioner's powers of reconstruction. In the light of this conclusion, this next part of the paper will consider whether the United States GAAR could be used to counteract the actions of the United States based parent companies.

10 A The United States Judicially Developed Anti-Avoidance Rule Prior to 2010 the United States had a judicially developed antiavoidance rule. First established in Gregory $v$ Helvering, the rule was known as the economic substance doctrine. ${ }^{132}$ Given that the common law position on the economic substance doctrine has been incorporated 15 directly into $\S 7701(\mathrm{o})$, this part of this paper will first outline the economic substance doctrine before describing how it is applied within the new statutory rule.

The economic substance doctrine seeks to prevent tax avoidance and evasion by finding that certain transactions have no real effect. ${ }^{133}$

20 The doctrine is an example of the courts taking a substance over form approach to the enforcement of tax law. ${ }^{134}$ In Gregory $v$ Helvering the Supreme Court first set out the substance over form test in finding that corporate structures and reorganisations could not be used to hide the true character of the arrangement. ${ }^{135}$ The corollary of this is that the

25 court was of the view that business decisions should not be made for the sole purpose of avoiding tax. ${ }^{136}$ While the court recognised that taxpayers have the right to minimise their taxes, the taxpayer did not win the case because the transactions in question were beyond the intention of the statute. ${ }^{137}$ The substance over form approach was also

30 made explicit in Commissioner v Court Holding Co, where the court stated that " $[\mathrm{t}]$ he incidence of taxation depends on the substance of a transaction." $" 138$

\footnotetext{
${ }^{132}$ Gregory v Helvering 293 US 465, at 469 (1935).

${ }^{133}$ Erik M Jansen "Legislative and Regulatory Responses to Tax Avoidance: Explicating and Evaluating the Alternatives" (2012) 57 St Louis U LJ 1, at 29.

${ }^{134}$ Philip Sancilio "Clarifying (or is it Codifying) the "Notably Abstruse": Step Transactions, Economic Substance, and the Tax Code" (2013) 113 Columbia Law Review 138 at 139.

${ }^{135}$ Gregory v Helvering, above n 132, at 469.

${ }^{136}$ Gregory v Helvering, above n 132, at 469.

${ }^{137}$ Gregory v Helvering, above n 132, at 470.

${ }^{138}$ Commissioner v Court Holding Co 324 US 331 (1945) at 334.
} 
The overall rule is said to be that "[i]f a transaction is devoid of economic substance ... it simply is not recognized for federal taxation purposes." 139 The economic substance rule is a straightforward application of the substance over form approach in that it involves looking behind the form of the transaction at the economic substance and effect of the transactions in question.

Despite the rule developing for close to eighty years, there is no uniform definition of what economic substance means. ${ }^{140}$ One line of cases suggested that there is a two pronged test asking first if the

10 transaction was motivated by a tax benefit purpose and second if there is no expectation of profits. ${ }^{141}$ If either of these elements is present the transaction will be found to have no economic substance. The alternative approach suggested in a separate line of cases was to view business purpose and objective profit potential as factors that might

15 inform the court's analysis of whether the transaction meets the economic substance criteria, rather than taking a strict two prong approach. ${ }^{142}$ As the law developed, the common factor was that if the taxpayer could not establish that there was a non-tax benefit to the transaction, it would be deemed to have no economic substance. ${ }^{143}$ It

20 has also been suggested that determination of economic substance may sometimes require a comparison of the tax and non-tax benefits. ${ }^{144}$ This comparison is necessary because the taxpayer may sometimes be able to show legitimate business goals behind the transactions, but these benefits may be insignificant in relation to the tax savings

25 received. The uncertainty and conflict regarding the approach to be taken was one of the reasons behind insertion of the statutory GAAR in s $7701(0) .{ }^{145}$

On the face of it, this approach appears to be narrower than the application of the New Zealand GAAR, because it only involves 30 consideration of the economic substance of the transactions. In Ben Nevis, the New Zealand Supreme Court held that a number of factors

${ }^{139}$ Lerman v Commissioner of Internal Revenue $939 \mathrm{~F} 2 \mathrm{~d} 44$ (3rd Cir 1991) at [4].

${ }^{140}$ T Christopher Borek, Angelo Frattarelli and Oliver Hart "Tax Shelters or Efficient Tax Planning? A Theory of the Firm Perspective on the Economic Substance Doctrine" (2013) Discussion Paper No 747, Harvard Law School at 4.

${ }^{141}$ See for example Rice's Toyota World v Commissioner 752 F 2d 89 (4th Cir 1985) at 91-92.

${ }_{142}$ ACM Partnership v Commissioner 157 F 3d 231 (3rd Cir 1998) at 247.

${ }^{143}$ Borek, Frattarelli and Hart, above n 140, at 5.

${ }^{144}$ Karen C Burke "Reframing Economic Substance" (2011) 31 Virginia Tax Review 271 at279.

${ }^{145}$ Mik Shin-Li "Strictly Wrong as a Tax Policy: The Strict Liability Penalty Standard in Noneconomic Substance Transactions (2010) 78 Fordham Law Review 2009 at 2019. 
might be relevant to the question of whether a tax avoidance arrangement exists, and that the "the ultimate question is whether the impugned arrangement ... makes use of the specific provision in a manner that is consistent with Parliament's purpose." 146

Despite appearing to involve a much narrower analysis, the New Zealand and United States GAARS are relatively similar. The economic substance doctrine has also been taken to be a rule applying the congressional intent and purpose when enacting the code. ${ }^{147}$ This is comparable to the parliamentary contemplation test as set out in Ben

10 Nevis. For example, in Coltec Industries Inc. $v$ United States the economic substance doctrine was described as a "judicial effort to ... prevent taxpayers from subverting the legislative purpose of the tax code". ${ }^{148}$ If the view in Coltec is accepted, then the United States judicial doctrine does not appear to be significantly different from the

15 New Zealand rule.

B The United States Statutory Rule

A codification of the judicial rule was attempted in 2010 with the introduction of $\S 7701$ (o) of the Internal Revenue Code $1986 .{ }^{149}$ The key provision is: ${ }^{150}$

\section{(1) Application of doctrine}

In the case of any transaction to which the economic substance doctrine is relevant, such transaction shall be treated as having economic substance only if -

(A) the transaction changes in a meaningful way (apart from Federal income tax effects) the taxpayer's economic position, and

(B) the taxpayer has a substantial purpose (apart from Federal income tax effects) for entering into such transaction.

The statutory economic substance doctrine is further defined to include "the common law doctrine", and the doctrine applies only to transactions that "[do] not have economic substance or [lack] business purpose." 151 That is, in order for transactions to be respected for tax

\footnotetext{
${ }^{146}$ Ben Nevis, above $\mathrm{n} 85$, at [109].

${ }^{147}$ For example, in Commissioner v Court Holding Co, above n 138 at 334.

148 Coltec Industries Inc v United States 454 F.3d 1340 (Fed Cir 2006) at 1353.

149 The rule was introduced in the Health Care and Education Reconciliation Act 2010.

${ }^{150}$ Internal Revenue Code 26 USC $\$ 7701(0)(1)$.

${ }^{151}$ Internal Revenue Code 26 USC $§ 7701(0)(5)(A)$.
} 
purposes, they must have both economic substance and a business purpose. Section 7701(o) is therefore an explicit incorporation of the existing common law rule into statute.

The definition of transaction in $\S 7701(\mathrm{o})$ includes a series of transactions. ${ }^{152}$ As a consequence, a case can be approached either from the point of view of one single transaction, or it can be approached by looking at the scheme as a whole when determining whether there is economic substance or not. ${ }^{153}$ The court has the ability to disaggregate the steps involved unless the taxpayer can show that the individual steps contributed to an overall non-tax purpose that is consistent with Congressional intent. ${ }^{154}$ If there are multiple steps in a scheme, the step doctrine means that the court can view the scheme as giving rise to one single transaction, rather than breaking it down into multiple steps that the rule may or may not apply to 15 individually. ${ }^{155}$

The overall approach to be taken therefore is to first determine whether there was a transaction that the economic substance doctrine is relevant to, and secondly to apply the statutory provisions to determine whether the economic substance doctrine applies. ${ }^{156}$

20 There are two statutory steps in applying the economic substance doctrine. In order for the transactions to have economic substance there is first an objective test to determine whether the transaction has meaningfully changed the taxpayer's economic position. ${ }^{157}$ The second element is subjective, and requires consideration of whether the 25 taxpayer had a substantial non-tax purpose for the transaction. ${ }^{158}$ In order to find that the transaction had no economic substance and is therefore void, one or both of these elements must be lacking. ${ }^{159}$ This clear statement of the two steps clarifies the common law position where it was questionable whether the economic substance doctrine 30 had two or three steps. ${ }^{160}$

Under the codified rule, a transaction's potential for profit will only be taken into account if the "present value of the reasonably expected

\footnotetext{
${ }^{152}$ Internal Revenue Code 26 USC $\S 7701(0)(5)(D)$.

153 Jansen, above n 133, at 35.

154 Burke, above n 144, at 276-277.

${ }^{155}$ Crenshaw v United States 450 F 2d 472 (5th Cir 1971).

156 Stephanie Teitsma "Tax Practise in Bumper Cars: Bumping into the "Relevant" Hazards of the Codified Economic Substance Doctrine" (2011) 37 Michigan Tax Lawyer 25 at 25 .

${ }^{157}$ Internal Revenue Code 26 USC $\S 7701(0)(1)(A)$.

${ }^{158}$ Internal Revenue Code 26 USC $\S 7701(0)(1)(B)$.

159 Jansen, above n 133, at 29.

160 Shin-Li, above n 145, at 2017.
} 
pre-tax profit is substantial in relation to the present value of the claimed net tax benefits." 161

$1 \quad$ Objective element: meaningful change to taxpayer's position

Under the objective element, there are two possible approaches. The

5 first is to determine whether any economic benefit was obtained. This was the approach taken by the Federal Circuit in Coltec Industries $v$ United States. ${ }^{162}$ The alternative approach is to look for the potential for profit, often defined as being potential for profit that is more than nominal. ${ }^{163}$ This must be done consistently with $\S 7701(\mathrm{o})(2)(\mathrm{A})$.

102 Subjective element: substantial non-tax purpose?

The courts have used at least seven different factors when determining a taxpayer's subjective business purpose behind entering a transaction: ${ }^{164}$

The following evidence has been considered by the courts: (i) whether a profit was even possible; (ii) whether the taxpayer had a nontax business reason to engage in the transaction; (iii) whether the taxpayer, or its advisors, considered or investigated the transaction, including the market risk; (iv) whether the taxpayer really committed capital to the transaction; (v) whether the entities involved in the transaction were entities separate and apart from the taxpayer and engaging in legitimate business before and after the transaction; (vi) whether all the purported steps were engaged in at arms-length with the parties doing what the parties intended to do; and (vii) whether the transaction was marketed as a tax shelter in which the purported tax benefit significantly exceeded the taxpayer's actual investment.

$3 \quad$ Penalties

The onus is on the taxpayer to establish that the deductions claimed or the transactions in question have economic substance. ${ }^{165}$ If either of the elements of the economic substance doctrine are lacking, a strict

\footnotetext{
${ }^{161}$ Internal Revenue Code 26 USC $\S 7701(0)(2)(\mathrm{A})$.

162 Coltec Industries Inc v United States, above n 148, at 1358.

163 Sheldon v Commissioner 94 TC 738 (1990) at 768.

164 Donald L Korb "The Economic Substance Doctrine in the Current Tax Shelter Environment" (remarks presented at the University of Southern California Tax Institute, 2005).

165 Shin-Li, above n 145, at 2018.
} 
liability penalty applies. ${ }^{166}$ As it is a strict liability provision, it will not be relevant whether you intended to avoid tax or not. However, it seems unlikely that there would be a situation of unintended tax avoidance that would fall within this rule due to the requirement that the subjective element of the two-part test is satisfied.

C Application of the United States GAAR to the Parent Company This section will consider whether $\S 7701(\mathrm{o})$ and the economic substance doctrine could be used to counteract the Double Irish and Dutch Sandwich structures. This analysis will proceed on the basis

10 that the parent company is located in the United States.

The first step is to determine whether there is a transaction that the economic substance doctrine could apply to. Depending on the approach taken, the transaction in question could be defined in two ways. First, it could be defined as the single licensing transaction

15 where the parent company licenses its intellectual property to subsidiary B in return for low royalty fees. Alternatively, the transaction could be defined as the scheme as a whole giving rise to an overall shifting of profits offshore.

1 Application of the doctrine to the single licensing transaction

20 If the transaction is defined as the single licence transaction to subsidiary $\mathrm{B}$, the second step is to determine whether the economic substance doctrine applies. In order to have economic substance, the transaction must have meaningfully changed the taxpayer's economic position. Under the view taken in Sheldon $v$ Commissioner, the

25 transaction did not result in an increased potential for profit that is more than minimal. The transaction did not create any new revenue making opportunities, nor did it reduce any expenses. The only way in which profit was increased was through the reduced tax bill as a result of shifting the income stream, and it is clear from the wording of $\S$

$307701(\mathrm{o})$ that the change in economic position must be more than a Federal income tax effect. ${ }^{167}$ A similar result is reached using the economic benefit analysis proposed in Coltec Industries. ${ }^{168}$ It is likely that a court would find that the transaction in question has not meaningfully changed the taxpayer's economic position.

35 Where one element of the economic substance doctrine is not met the transaction will be ignored for income tax purposes. In the case

\footnotetext{
${ }^{166}$ Internal Revenue Code 26 USC $\S 6662(b)(6)$. The penalty is generally $20 \%$, but increases to $40 \%$ where the transaction was not adequately disclosed.

${ }^{167}$ Internal Revenue Code 26 USC $\$ 7701$ (o)(1)(A).

${ }^{168}$ Coltec Industries Inc $v$ United States, above n 148.
} 
that the above analysis of the economic position is not correct, the subjective element will also be considered. The subjective element requires the court to look at whether there was a substantial non-tax purpose for the transaction. This will involve consideration of a multitude of factors. For the single licensing agreement, the important factors are whether there was a non-tax business reason for the transaction, the separation or otherwise of the entities involved and whether the arm's length principle was complied with.

The intellectual property rights being transferred to subsidiary B

10 were largely developed and protected in the United States. If the intellectual property protection was not sufficient, this might be a nontax purpose for licensing of substantial assets to an overseas subsidiary. However, the United States intellectual property regime is comprehensive and it is unlikely they would develop their inventions

15 in the United States without sufficient protection. This would indicate that there is no intellectual property reason for the licensing transaction.

There is also no company law reason for the licensing agreement. The parent company has an existing company structure that can deal

20 with the income and financial issues, indicating that the transfer was likely motivated by tax benefits. It would be difficult for the taxpayer to make an argument that the transaction was not motivated by tax when the rights could have been used and exploited just as easily in the United States. As with many of the arguments made in relation to the

25 Double Irish and Dutch Sandwich structures, this step of the analysis is highly fact specific and the outcome could turn on the presence or absence of small details.

In the case of a company such as Apple, there may be a foundation for an argument that there was a non-tax purpose for the transaction if

30 the split of the local and international sales is taken into account. Apple has split their local and international sales since 1980, meaning that on-going licence agreements are merely a continuation of the split in assets. There might be a stronger argument that the transaction has no business purpose if the company had historically carried out all

35 their business in one place, and then suddenly shifted part of the business offshore with no apparent reason other than tax benefits.

As described in Part V, the licence agreement is a transfer pricing arrangement, and must be done at arm's length. Exploitation of the arm's length principle is another factor that may indicate that the 40 taxpayer was not motivated by a legitimate business purpose. In this 
case, the parent company is able to exploit the arm's length principle relatively easily owing to the previously described characteristics of intellectual property that make an accurate valuation extremely difficult.

5 It is likely that a court would find that in the general structure described in Part II the taxpayer did not have a subjective business purpose behind the transaction. The consequence is that at least one, probably both, of the elements required for a transaction to have economic substance would not be found, and the transaction would be void for income tax purposes.

The final step in the analysis is the imposition of strict liability penalties under $\S 6662$. Assuming that the transaction is being ignored for tax purposes, the penalty provision would apply because there has been a substantial underpayment of tax. The consequence of this is

15 that the parent company would have to pay income tax on all its income, with a $20 \%$ penalty on top of that. This would likely amount to a penalty in the millions of dollars and a tax bill in the billions for companies such as Google. ${ }^{169}$

2 Application of the doctrine to the scheme as a whole

20 An alternative analysis can be made taking the defined transaction to include the whole scheme. This would include the setting up of the two Irish incorporated subsidiaries, the re-location of the centre of management of subsidiary $\mathrm{B}$ to a tax haven, and the licensing arrangements that allow the shifting of profits.

25 When applying the economic substance doctrine to the scheme as a whole, many of the relevant factors were also factors in application to the single licensing agreement. The analysis, therefore, is very similar. The only change in economic position arises because of the increased profits as a result of a decreased tax bill. The argument here is even stronger because of the fact that subsidiaries $\mathrm{S}$ and $\mathrm{N}$ have no economic purpose other than to avoid paying taxes. The income being received by them and funnelled to subsidiary B is the same income that would otherwise be coming into the parent company, and there are no additional products or rights being sold or used. The presence of shell

35 entities means the argument that there is no economic purpose is stronger when the transaction is defined more broadly.

In the event that an argument could be made that the economic position has changed as a result of using the Double Irish and Dutch

${ }^{169}$ Google are thought to be avoiding a tax bill of billions of dollars per year. See Sokatch, above n 4 , at 726. 
Sandwich transactions, the relevant factors under the second element must be considered. No arguments have been raised that might establish a non-tax business reason for the transaction, and the fact that at least one of the Irish subsidiaries and the Dutch subsidiary are shell companies would tend to support this view. ${ }^{170}$ The arguments raised earlier in regard to the transfer pricing agreements are also stronger in the context of the scheme as a whole because multiple payments and transfers are involved. The first royalty payment from subsidiary B to the parent company is significantly less than the payments from

10 subsidiary $\mathrm{S}$ to subsidiary $\mathrm{B}$, despite the agreements involving the same rights and products. This is a strong indication that the transfer pricing rules are being exploited and this leads to a conclusion that there was probably not a substantial non-tax purpose for the transaction.

15 The likely conclusion is that it would not make a difference whether the transaction was framed to be the scheme as a whole or the individual transactions, and that both would be found not to comply with the economic substance doctrine. The consequence of this finding is that the parent company would have to pay income tax on all

20 income, whether or not it was being received directly by the parent company. They would also be obligated to pay a significant $20 \%$ penalty.

\section{Enforcement}

Similarly to the New Zealand rule, application of the United States rule

25 would likely have practical difficulties in regard to enforcement. The profits are sitting in an offshore account and a true representation of them may be difficult to determine. Because the United States does not have double tax treaties with many of the true tax havens, the exchange of information that would facilitate the determination of the

30 profits becomes much more difficult. ${ }^{171}$ As the United States has a double tax treaty with Ireland, they would be able to receive information on subsidiary $\mathrm{S}$, which is based in Ireland. But information about subsidiary B would not be available, as it is not deemed to be an Irish tax resident. The problem of this is that the

35 income derived by subsidiary $S$ would be clear, but any expenses incurred or deductions available to subsidiary B or the parent company

\footnotetext{
170 That is not to say that an argument of this nature could not be made. Analysis of any structures of this nature is very fact dependent, and the outcome of each case will vary.

${ }^{171}$ The same is also true of New Zealand. See Jillian Lawry Guide to Taxing Internet Transactions (CCH New Zealand, Auckland, 2000) at 1005.
} 
would need to be taken into account when the authorities are assessing the income of the parent company.

From the above, it becomes clearer that the transaction would need to be defined broadly as meaning the entire scheme. If the transaction were defined narrowly as meaning the initial licence agreement only, no information about profits being made from the intellectual property would be available to the authorities when assessing the income tax of the parent. The only avenue for altering the level of income tax would be for the authorities to re-value the assets being licensed under the

10 arm's length rule. However, as discussed in Part III, there are inherent difficulties in accurately estimating the value of intellectual property unless the income received from it is clear. A further limitation on any remedy gained under the arm's length rule is that the transaction cannot take into account the profits made, only the strict value of the assets.

The reliance on international cooperation and the enforcement difficulties faced by the authorities in regard to the taxation of multinational enterprises illustrates one of the fundamental flaws in the western taxation system. The current tax system developed at a time

20 where multinational enterprises were not common, and taxation was more straightforward. As a consequence, the tax rules operate on the assumption that different entities of a multinational operate independently of one another. Technological developments mean that this no longer holds true, and it is likely that these multinationals are in 25 reality operating as one global enterprise. ${ }^{172}$

A finding that the Double Irish and Dutch Sandwich structures employed by many technology-based firms do not have economic 30 substance could potentially have a flow on effect, regardless of the enforceability of the penalty provisions. Large multi-national corporations rely on their branding and image to help maintain their profitability. If the companies were seen to be not complying with the Internal Revenue Service, there is the potential for this to result in a 35 public backlash of sorts. An analogous situation arose in the United Kingdom when Starbucks were reported to have paid only UKP 8.6 million in taxes over 15 years of trading, and none was paid in the last

${ }^{172}$ Levin and McCain, above $\mathrm{n} 21$, at 10. 
three years. ${ }^{173}$ The resulting public outcry caused Starbucks enter an arrangement to repay UKP 10 million in taxes they had avoided. ${ }^{174}$ While this is clearly not a solution that should be relied on as it will come down to the decisions of each individual company, it is possible that compliance with the Internal Revenue Service might be provoked by public opinion on the matter.

\section{Does Use of the Commissioner's Powers of} Reconstruction Implicate the Separate Entity Doctrine?

Both New Zealand and the United States have strong separate entity

10 doctrines. In general, a corporation is considered to be a separate legal person. That is, the corporation and its owners or shareholders are to be treated separately at law. ${ }^{175}$ In order for either the New Zealand GAAR or the United States GAAR to be enforced effectively, the relevant revenue authorities will be essentially ruling that the income of one entity can be attributed to another entity.

A New Zealand

The separate entity principle in New Zealand is founded on the House of Lords ruling in Salomon $v$ Salomon \& Co, ${ }^{176}$ holding that a company is a separate legal entity from its shareholders or owners. ${ }^{177}$

20 Extension of this principle means that a subsidiary is considered to be a separate legal person from its parent company. This is because the parent company is a 100 per cent shareholder of the subsidiary. The consequence of this is that in order for the Commissioner to attribute the income of subsidiary B in the Double Irish or Dutch Sandwich

25 structure to the parent company, they are essentially disregarding the separate entity status of the companies. While the separate entity doctrine in New Zealand has traditionally been strong, there are several instances of the courts piercing the corporate veil to impose liabilities of the company on to a shareholder. ${ }^{178}$

\footnotetext{
${ }^{173}$ Terry MacAlister "Starbucks Pays Corporation Tax in the UK for the First Time in Five Years" (23 June 2013) <www.theguardian.com>.

${ }^{174}$ MacAlister, above $\mathrm{n} 173$.

${ }^{175}$ Douglas G Smith "A Federalism-Based Rationale for Limited Liability" (2009) 60(3) Alabama Law Review 649 at 652.

176 Salomon v Salomon \& Co (1897) AC 22 (HL). This is reinforced by the Companies Act 1993, s 15.

${ }^{177}$ Salomon v Salomon, above n 176, at 51.

${ }^{178}$ See for example Official Assignee v 15 Insoll Avenue Ltd [2001] 2 NZLR 492 (HC).
} 
In the tax context, arguments relating to the separate entity doctrine and the corporate veil are often made implicitly. In Russell $v$ Commissioner of Inland Revenue (Russell), the appellant contested the Commissioner's reconstruction after it was found that the appellant had engaged in tax avoidance. ${ }^{179}$ Initially, the Commissioner reconstructed the income of the relevant partnership and corporate entities to the appellant. The appellant submitted that the company structure he used was entirely permissible, and that the Commissioner could not reconstruct the income in question to him because it was the companies that earned the income, not him. ${ }^{180}$

The Court of Appeal concluded that the Commissioner's broad powers enabled them to make this reconstruction. The fact that the business structures were not used for genuine business reasons, the extensive financial consequences and the lack of tax paid by the

15 appellant over the relevant time period were strong factors in favour of a finding that the income should be attributed to the appellant. ${ }^{181}$ The appellant was the governing mind of the arrangements and was affected by the arrangement in a similar manner to the taxpayers in Penny $v$ Commissioner of Inland Revenue. ${ }^{182}$

20 The New Zealand courts have at times disregarded the separate entity doctrine, and there is tax precedent for attributing company income to the shareholders. However, the Court of Appeal in Russell recognised that "it is not inevitable that a tax avoidance arrangement by a company will or should be attributed to a shareholder". ${ }^{183}$ The

25 indication is therefore, that whether the separate entity doctrine poses a problem for application of the GAAR will be fact dependent.

The Double Irish and Dutch Sandwich structures have similarities to the arrangement in Russell in that they have extensive economic consequences, and the companies involved were completely 30 controlled by the parent company that is the 100 per cent shareholder. Therefore, the separate entity doctrine is unlikely to pose a significant

${ }^{179}$ Russell v Commissioner of Inland Revenue [2012] NZCA 128; 201225 NZTC 20-120.

${ }^{180}$ Russell v Commissioner of Inland Revenue, above n 179, at [68].

${ }^{181}$ Russell v Commissioner of Inland Revenue, above n 179, at [72].

${ }^{182}$ In Penny, the Supreme Court emphasised that it is not the actual use of a company to arrange one's affairs that gives rise to tax avoidance, but rather, it is the artificial way in which the structures are used. See Penny $v$ Commissioner of Inland Revenue, above $\mathrm{n}$ 86, at [47]. In that case, the appellant orthopaedic surgeons transferred their business into a company, and paid themselves artificially low salaries. The remainder of the income was distributed to family trusts in the form of dividends.

${ }^{183}$ Russell v Commissioner of Inland Revenue, above n 179, at [74]. 
problem for application of the GAAR to the parent company if a rule such as that in New Zealand were to be applied.

B The United States

Application of the United States GAAR is slightly more difficult than

5 the New Zealand GAAR. The difficulties with enforcement and information gathering, combined with the strength of the separate entity doctrine mean that it would be difficult for the Internal Revenue Service to bring a successful case under the United States GAAR.

The separate entity doctrine in the United States has a sound 10 historical basis, and it has been noted by the Supreme Court that "[1]imited liability is the rule not the exception", ${ }^{184}$ indicating that it holds a fundamental role in corporate law. Thus there is a strong foundation for an argument that the income of the subsidiary companies in the Double Irish and Dutch Sandwich structures should not be attributed to the parent company. However, the courts have historically recognised that in certain cases the separate legal status of the entities should be disregarded. ${ }^{185}$

The strength of the separate entity doctrine is such that the corporate veil will only be pierced in rare cases: ${ }^{186}$

Courts typically require the party seeking to pierce the corporate veil to demonstrate that there is significant shareholder domination and control over the corporation whose veil is to be pierced, that there is an element of fraud in the use of the corporate entity that warrants dispensing with limited liability, and that the fraudulent use of the corporate form has caused some injury to the party seeking to pierce the corporate veil.

30 There is no strict rule on whether the corporate veil can be pierced, so any decision will be highly fact dependent. However, the burden on the plaintiff to displace the separate entity rule is severe, and the courts are in general reluctant to pierce the corporate veil because it is an "extreme remedy, sparingly used." 187

\footnotetext{
${ }^{184}$ Anderson v Abbott 321 US 349 at 362 (1944).

185 This is often referred to as lifting or piercing the corporate veil. The corporate veil sits between the company and its owners, and represents the separate legal status of the two.

${ }^{186}$ Smith, above n 175, at 657.

187 Sonora Diamond Corporation v Superior Court 99 Cal Rptr 2d 918 at 922 (1992).
} 
In regard to the Double Irish and Dutch Sandwich transactions described in Part II, it appears unlikely that the courts would be willing to pierce the corporate veil and attribute the income of the subsidiaries to the parent company. If the parent company wished to contest the Commissioner's restatement of the company's income, they would be able to make an argument that the strength of the separate entity doctrine prevents the Commissioner from making such a ruling.

If the Commissioner wished to make a counter argument that they 10 are entitled to make such a ruling, they would first have to show that there is domination and control of the subsidiary by the parent company. ${ }^{188}$ The nature of the parent-subsidiary relationship is such that the parent company will almost certainly be involved in the affairs of the subsidiary. Thus, a stronger argument than basic control

15 is necessary, ${ }^{189}$ and there should be evidence of the parent company's involvement in the day-to-day operations of the subsidiary. ${ }^{190}$ Use of a shell company is evidence of this. The shell company, for example subsidiary $\mathrm{N}$, has no employees and cannot make any decisions for itself. The parent company is completely running the affairs of the 20 subsidiary.

The second requirement is that there was a misuse or abuse of the corporate form equating to fraud or injustice. ${ }^{191}$ That is, the corporation must exist with no other purpose than fraud. The subsidiaries in question exist solely for the purpose of enabling tax

25 avoidance and have no substantial business purpose. Difficulties may arise at this step of the analysis if some of the subsidiaries are shell companies and some are not. For example, in the specific structure used by Apple, Apple Operations International is a shell company with no employees, while Apple Sales International has 250

30 employees and substantial offshore operations. Therefore, generation of offshore income is done by both shell entities, and entities that have commercial operations. This creates a difficulty because attributing only part of the offshore income to the parent company does not achieve the desired result.

35 The final requirement is that the fraud or wrong must result in some type of injury to the plaintiff. ${ }^{192}$ The injury that the Commissioner

\footnotetext{
188 Smith, above n 175, at 657.

${ }^{189}$ Smith, above n 175, at 657.

190 Sonora Diamond Corporation v Superior Court, above n 187, at 838.

${ }^{191}$ Smith, above n 175, at 658 .

192 Smith, above n 175, at 659.
} 
would argue for is that they have received an inadequate amount of tax from the parent company and that the amount received is not an accurate representation of the income of the parent company. This final step is also contentious. It is not clear whether this would be a sufficient injury, as the standard for actual injury is typically high.

The strength of the separate entity doctrine in the United States means that the Internal Revenue Service and courts are typically reluctant to attribute the activities of an affiliate company to the parent organisation. ${ }^{193}$ In the light of this, an argument based on the above

10 analysis may be tenuous and unlikely to succeed. As a result, the revenue authorities would potentially not want to intervene and attribute the income of the subsidiary to the parent company at risk of having their findings challenged. That is, the existence of the separate entity doctrine may be a factor in tipping a finely balanced case in

15 favour of the taxpayer.

C An Alternative Resolution for the Corporate Veil Argument Given the extent of the problem and the strong interest of the government in remedying the situation, a broader approach is perhaps needed. The approach taken by the United Kingdom Supreme Court

20 in Prest $v$ Petrodel Resources Ltd is an example of a formulation of the rule that might better fit this scenario if it were to be proposed by the Commissioner. ${ }^{194}$ Lord Sumption proposed a rule that: ${ }^{195}$

... applies when a person is under an existing legal obligation or liability or subject to an existing legal restriction which he deliberately evades or whose enforcement he deliberately frustrates by interposing a company under his control. The court may then pierce the corporate veil for the purpose ... of depriving the company or its controller of the advantage they would otherwise have obtained by the company's separate legal personality.

This rule continues the theme of having a narrow formulation in order to best uphold the separate entity doctrine, while providing a clearer 35 platform for parties to argue that the corporate veil should be pierced. An approach like this creates a favourable argument for the tax authorities to pierce the corporate veil as the company structures

193 George E Constantine "Recent IRS Determination Highlights Importance of Separation Among Affiliates" (2011) Association Law and Policy.

194 Prest $v$ Petrodel Resources Ltd and Others [2013] UKSC 34.

${ }^{195}$ Prest v Petrodel Resources Ltd and Others, above n 194, at [35]. 
employed are deliberately frustrating the law. This would enable the tax authorities to attribute the income of the subsidiaries to the parent company for income tax purposes.

\section{Conclusion}

5 The Double Irish and Dutch Sandwich structures used by large multinational enterprises raise several issues in relation to the nature of the western tax system itself. Close analysis of the structures reveals that they are used to exploit the different bases of taxation. In the United States, corporate tax is based on place of incorporation. By contrast,

10 the Irish tax system taxes companies on the basis of management and control. This difference forms the foundation for a scheme which enables entities such as Apple Inc to shift its offshore operations to Ireland, and with the use of shell entities and internal transactions, they are able to avoid paying tax on billions of dollars of income. ${ }^{196}$

15 Use of these structures causes significant problems from both an economic perspective, and also from the intellectual property point of view. The companies in question typically argue that they are having a positive rather than negative effect on the economy. This argument is based on the job creation, product development and services

20 provided by the company. However, despite an increasing GDP, corporate tax now forms a record low percentage of federal taxes. The consequence of this is that the government is missing out on valuable funds at a time where federal debt is at a record high.

The Double Irish and Dutch Sandwich are also problematic from

25 the intellectual property point of view. One of the key justifications for providing intellectual property protection is that creation of rights and protection of products encourages innovation. Shifting profits and some of the associated economic activity offshore results in a lack of connection between the state where the incentive to work is

30 provided and the state where the profits reside. The result is that the Double Irish and Dutch Sandwich are exploiting both the tax system and the strong intellectual property protection provided in the United States.

The key component of this paper was an analysis of whether a 35 GAAR in the form of New Zealand's or the United States' could be used to take action against the Double Irish and Dutch Sandwich.

${ }^{196}$ In 2011, Apple avoided paying corporate tax on \$22 billion of profits made offshore. 
Analysis of the bare structures described suggests that it would be possible for the GAAR to apply in some cases, but that this is not a certainty. Application of the GAAR is very fact specific, so the success or otherwise would depend on the exact facts at issue. Factors that might tip the analysis in favour of the Commissioner include a sudden change in set up, use of shell companies, or repatriation of the funds that were previously residing offshore.

There is also a practical difficulty in New Zealand with the application of the Commissioner's powers of reconstruction. Analysis

10 of the Double Irish and Dutch Sandwich revealed the difficulty in undertaking an accurate reconstruction of the income in question.

Following this, application of the United States GAAR was also considered. The economic substance doctrine was found to apply in a similar manner to the New Zealand GAAR. At the most basic level, the

15 transactions do not appear to have any economic substance, as the only change in economic position is as a result of the reduction in tax liability. The transactions would therefore be ignored for income tax purposes.

Application of both the New Zealand GAAR and the United States

20 gaar revealed that framing the arrangement or transaction as the entire scheme would help form a more solid foundation for a case. However, in both countries, application of the rules is highly fact specific and would be difficult to ascertain.

The final part of the paper considered whether the separate entity 25 doctrine would be implicated by application of a GAAR. This section reveals that the separate entity doctrine is stronger in the United States than in New Zealand. As a result, application of the United States GAAR in a way that disregards the separate entity status of the subsidiaries becomes more contentious.

30 The inability to make out a clear case for application of a GAAR to the Double Irish and Dutch Sandwich structures indicates that multijurisdictional co-operation will be required if the negative effects of these tax practises are to be reduced. The paper also illustrates one of the fundamental deficiencies in our current tax system, that is, the 35 inability to regulate and control intangible resources and technology based transactions. 


\section{Bibliography}

A Cases

$1 \quad$ New Zealand

$5 \quad$ Alesco New Zealand Ltd v Commissioner of Inland Revenue [2013] NZCA 40.

Ben Nevis Forestry Ventures Ltd \& Ors $v$ Commissioner of Inland Revenue [2008] NZSC 115, [2009] 2 NZLR 289.

BNZ Investments Ltd v Commissioner of Inland Revenue (2000) 19

10 NZTC 15,732 (HC).

Case W33 (2004) 21 NZTC 11,321.

Challenge Corporation v Commissioner of Inland Revenue (1986) 2

NZLR 513 (PC).

Commissioner of Inland Revenue v Gerard [1974] 2 NZLR 279 (CA).

15 Elmiger v Commissioner of Inland Revenue [1966] NZLR 683.

Glenharrow Holdings Ltd v Commissioner of Inland Revenue [2008] NZSC 116, [2009] 2 NZLR 359.

Hadlee v Commissioner of Inland Revenue [1989] 2 NZLR 447 (HC).

Hadlee v Commissoner of Inland Revenue [1991] 3 NZLR 517 (CA).

20 Miller (No. 1) v Commissioner of Inland Revenue (1997) 18 NZTC $13.001(\mathrm{HC})$.

Miller v Commissioner of Inland Revenue [1999] 1 NZLR 275 at 279 (CA).

Miller v Commissioner of Inland Revenue [2001] 3 NZLR 316 (PC).

25 Penny v Commissioner of Inland Revenue [2011] NZSC 95.

Peterson v Commissioner of Inland Revenue (No 2) (2002) 20 NZTC $17,761(\mathrm{HC})$.

Westpac Banking Corporation v Commissioner of Inland Revenue CIV 2005-404-2843 (HC).

\section{$2 \quad$ United States}

ACM Partnership v Commissioner 157 F.3d 231 (3rd Cir 1998).

Anderson v Abbott 321 US 349 (1944).

Coltec Industries Inc v United States 454 F.3d 1340 (Fed Cir 2006).

35 Commissioner v Court Holding Co 324 US 331 (1945).

Crenshaw v United States 450 F.2d 472 (5th Cir 1971).

Gregory v Helvering 293 US 465 (1935).

Lerman v Commissioner of Internal Revenue 939 F.2d 44 (3rd Cir 1991).

40 Rice's Toyota World v Commissioner 752 F.2d 89 (4th Cir 1985). 
Sheldon v Commissioner 94 TC 738 (1990).

Sonora Diamond Corporation v Superior Court 99 Cal Rptr 2d 918 (1992).

$53 \quad$ United Kingdom

Prest v Petrodel Resources Ltd and others [2013] UKSC 34.

$4 \quad$ Australia

Newton v Federal Commissioner of Taxation (1958) 11 ATD 442;

10 [1958] AC 450 (PC).

B Legislation

$1 \quad$ New Zealand

Companies Act 1993.

15 Copyright Act 1994.

Income Tax Act 2007.

Interpretation Act 1999.

Patents Act 1953.

Patents Act 2013.

20 Trade Marks Act 2002.

\section{$2 \quad$ United States}

Health Care and Education Reconciliation Act 2010.

Internal Revenue Code 26 USC.

25 Stop Tax Haven Abuse Act 2013.

$3 \quad$ Ireland

Finance Act 1999.

30 C Books and Chapters in Books

Andrea Amatucci (ed) International Tax Law (Kluwer Law International, The Netherlands, 2006).

Donald S Chisum and others Principles of Patent Law: Cases and Materials (2nd ed, Foundation Press, New York, 2001).

35 Hugh J Ault and Brian J Arnold Comparative Income Taxation: A Structural Analysis (3rd ed, Aspen Publishers, New York, 2010).

James R Repetti "The United States" in Hugh J Ault and Brian J Arnold (eds) Comparative International Taxation: A Structural Analysis (3rd ed, Aspen Publishers, New York, 2010) 173. 
Jillian Lawry Guide to Taxing Internet Transactions (CCH New Zealand, Auckland, 2000).

Michael J Graetz Foundations of International Income Taxation (Foundation Press, New York, 2003).

5 Philip W Grubb and Peter R Thomsen Patents for Chemicals, Pharmaceuticals, and Biotechnology: Fundamentals of Global Law, Practise and Strategy (5th ed, Oxford University Press, New York, 2010).

Roy Saunders and others The Principles of International Tax Planning

10 (Corpus Publishing, Gloucestershire, 2005).

Victor Thuronyi Comparative Tax Law (Kluwer Law International, The Hague, 2003).

William Cornish, David Llewelyn and Tanya Aplin Intellectual Property: Patents, Copyright, Trade Marks and Allied Rights (7th ed,

15 Sweet \& Maxwell, London, 2010).

D Journal Articles

Andrew Thomas and Alex Faseruk "A Teaching Note on Offshore Financial Centres" (2012) Journal of Advancements in Business

20 Education.

Charles C Engel "Revisiting the Value Added Tax: A Clear Solution to the Murky United States Corporate Tax Structure" (2012) 22 Ind Int'1 \& Comp Law Review 347.

Chris Evans "Barriers to Avoidance: Recent Legislative and Judicial

25 Developments in Common Law Jurisdictions" 37 Hong Kong LJ 103.

Denise R Johnson "Reflections on the Bundle of Rights" (2007) 32 Vt

L Rev 247.

Douglas G Smith "A Federalism-Based Rationale for Limited Liability” (2009) 60(3) Alabama Law Review 649.

30 Erik M Jansen "Legislative and Regulatory Responses to Tax Avoidance: Explicating and Evaluating the Alternatives" (2012) $57 \mathrm{St}$ Louis U LJ 1.

George E Constantine "Recent IRS Determination Highlights Importance of Separation Among Affiliates" (2011) Association Law

35 and Policy.

John J Cross "Taxation of Intellectual Property in International Transactions" (1988) 8 Virginia Tax Review 553.

John Hickson "Corporate Migrations to Ireland" (2010) 36 Int'l Tax Journal 25. 
John Sokatch "Transfer-Pricing with Sofware Allows for Effective Circumvention of Subpart F Income: Google's 'Sandwich' Costs Taxpayers Millions" (2011) 45 Int'1 Law 725.

John VanDenburgh "Closing International Loopholes: Changing the

5 Corporate Tax Base to Effectively Combat Tax Avoidance" (2012) 47 Val U L Rev 313.

Joseph B Darby "Double Irish More than Doubles the Tax Saving: Hybrid Structure Reduces US, Irish and Worldwide Taxation" (2007) 11(9) Practical US/International Tax Strategies 2.

10 Julie Harrison and Mark Keating "New Zealand's General AntiAvoidance Provisions: A Domestic Transfer Pricing Regime by Proxy?" (2011) 17 NZ J Tax \& Policy 419.

Karen C Burke "Reframing Economic Substance" (2011) 31 Virginia Tax Review 271.

15 Karen C Burke "Passthrough Entities: The Missing Element in Business Tax Reform” (2013) 40 Pepperdine Law Review 1329.

Michael J Graetz "Technological Innovation, International Competition, and the Challenges of International Income Taxation" (2013) Colombia Law Review 347.

20 Mik Shin-Li "Strictly Wrong as a Tax Policy: The Strict Liability Penalty Standard in Noneconomic Substance Transactions (2010) 78 Fordham Law Review 2009.

Philip Sancilio "Clarifying (or is it Codifying) the "Notably Abstruse": Step Transactions, Economic Substance, and the Tax 25 Code" (2013) 113 Columbia Law Review 138.

Reuven S Avi-Yonah "Corporate and International Tax Reform: Proposals for the Second Obama Administration (And Beyond)" (2013) 40 Pepperdine Law Review 1365.

Simon Loretz "Corporate Taxation in the OECD in a Wider Context" 30 (2008) 24 Oxford Review of Economic Policy 639.

Stephanie Teitsma "Tax Practise in Bumper Cars: Bumping into the "Relevant" Hazards of the Codified Economic Substance Doctrine" (2011) 37 Michigan Tax Lawyer 25.

Stephen C Loomis "The Double Irish Sandwich: Reforming Overseas

35 Tax Havens" (2012) 43 St Mary’s Law Journal 825.

Steven A Bank "Tax Advice for the Second Obama Administration: The Globalisation of Corporate Tax Reform" (2013) 40 Pepperdine Law Review 1307.

Tyler M Dumler "Charging Less to Make More: The Causes and 40 Effects of the Corporate Inversion Trend in the US and the 
Implications of Lowering the Corporate Tax Rate" (2012) UC Davis Business Law Journal 89.

W Wesley Hill and J Sims Rhyne “Opening Pandora's Patent Box: Global Intellectual Property Tax Incentives and Their Implications for

5 The United States" (2013) 53(3) IDEA - The Intellectual Property Law Review 371.

Xuan-Thao N Nguyen "Holding Intellectual Property" (2005) 39 Ga L Rev 1155.

10 E International Materials

Action Plan on Base Erosion and Profit Shifting, OECD (2013).

Convention Between the Government of Ireland and Government of the United States of America for the Avoidance of Double Taxation and the Prevention of Fiscal Evasion With Respect to Taxes on

15 Income and Capital Gains, Ireland-United States (signed 28 July 1997).

Directive 2003/49 on the Taxation of Cross-Border Interest and Royalty Payments in the European Union, OJ L 157, P. 0049 - 0054.

20 F Newspaper Articles and Internet Materials

Damian Paletta "With Tax Break, Corporate Rate is Lowest in Decades" (3 February 2012) Wall Street Journal <online.wsj.com>. Howard Gleckman “The Real Story On Apple's Tax Avoidance: How Ordinary It Is" (21 May 2013) <www.forbes.com>.

25 James Fryer "The Price Isn't Right: Corporate Profit Shifting has Become Big Business" (16 February 2013) <www.theeconomist.com>.

Peter Flanagan "How this Double Irish accountancy trick works" (27 May 2013) <www.independent.ie>.

30 Terry MacAlister "Starbucks Pays Corporation Tax in the UK for the First Time in Five Years" (23 June 2013) <www.theguardian.com>.

G Unpublished Papers

Donald L Korb "The Economic Substance Doctrine in the Current

35 Tax Shelter Environment" (remarks presented at the University of Southern California Tax Institute, 2005).

Jane G Gravellee "Tax Havens: International Tax Avoidance and Evasion" (2010) Congressional Research Service Paper 7-5700.

T Christopher Borek, Angelo Frattarelli and Oliver Hart "Tax Shelters

40 or Efficient Tax Planning? A Theory of the Firm Perspective on the 
Economic Substance Doctrine" (2013) Discussion Paper No 747, Harvard Law School.

H Official Sources

5 Inland Revenue Interpretation Statement: Tax Avoidance and the Interpretation of sections BG 1 and GA 1 of the Income Tax Act 2007 (13 June 2013).

Inland Revenue Tax Information Bulletin (Vol 12, No 10, October 2000).

I Speeches and Informal Sources

Carl Levin "Offshore Profit Shifting and the US Tax Code" (Opening statement to the US Senate Permanent Subcommittee on Investigations, 20 September 2012).

15 Carl Levin and John McCain "Offshore Profit Shifting and the US Tax Code - Part 2 (Apple Inc)" (memorandum to the Members of the Permanent Subcommittee on Investigations, 21 May 2013).

J Richard Harvey "Testimony Before the US Senate Permanent Subcommittee on Investigations" (21 May, 2013).

20 "Testimony of Apple Before The Permanent Subcommittee On Investigations" (US Senate, 21 May 2013). 